\title{
Results, problems and future tasks of palaeostress and fault-slip analyses in the Pannonian Basin: the Hungarian contribution
}

\author{
FoDOR, László \\ MTA-ELTE Geological, Geophysical and Space Science Research Group, 1117 Budapest Pázmány P. sétány 1/C, Hungary, \\ e-mail: lasz.Fodor@yahoo.com \\ orcid: https://orcid.org/0000-0002-0606-4414
}

\section{Feszültségmezố- és vetôminta-elemzés eredményei, problémái és további feladatai a Pannon-medencében: a magyar kutatók hozzájárulása}

Összefoglalás

A Pannon-medencében a modern paleofeszültség-meghatározás és töréses szerkezetelemzés Françoise BERGERAT, Jacques GEYSSANT and Claude LEPVRIER munkájával 1982-1984-ben kezdődött. Miután F. BERGERAT néhány magyar kutatónak megtanította a módszer terepi és laboratóriumi eszköztárát, a modern töréses szerkezetelemzés kiterjedt a Pannon-medence magyarországi részére, néhány azzal határos területre, és máig is tart. Ez a munka az elmúlt 35 év eredményeit, a meghatározott kainozoos feszültségmezóket, határaikat és meghatározási bizonytalanságaikat veszi számba, egyfajta tudománytörténeti nézőpontból. A kutatás során felállított szerkezetfejlődési modell egyre összetettebb lett, és egyre több részletet ismertünk fel mind az Alcapa, mind a Tisza-Dacia tektonikai egységek deformáció-történetében. A paleomágneses és feszültségmezô-adatok integrálásával igazoltuk, hogy a feszültségtengelyek és töréses elemek változása gyakran csak a kőzetblokkok függőleges tengely körüli forgásának köszönhetô, és nem tükrözi a feszültségmező tényleges forgását. A billentéstteszttel, a deformált kőzetek új radiometrikus kormeghatározásával és a felszíni és felszín alatti adatok együttes felhasználásával a feszültségmező-fejlődés nagyon finom tagolása és az irány szerint azonos mezők felújulásának kimutatása vált lehetségessé. A finomított fejlődéstörténeti modell segítségével néhány fázisra igazolni lehetett a heterogén feszültségmező fellépését. Az eredmények ellenére a töréses fázisok számát, egy adott fázis pontos időzítését és maximális feszültségtengelyének térbeli változásait a jövőben is vizsgálnunk kell. A deformált anyag reológiai viselkedésének és a töréses deformáció fizikai paramétereinek megértése szintén jövőbeni kutatási feladat, amelyet a deformációs szalagok, a folyadékzárványok és izotópok vizsgálatán keresztül végezhetünk el abból a célból, hogy jobban megértsük a deformáció, süllyedéstörténet, diagenezis és folyadékáramlás kapcsolatát.

Kulcsszavak: feszültségmezô, vetó, feszültségmeghatározás, forgás, kibillenés, Pannon-medence

Abstract

In the Pannonian Basin fault-slip analysis and palaeostress determinations started in 1982-1984 by the work of Françoise Bergerat, Jacques Geyssant and Claude Lepvrier. After F. Bergerat introduced some Hungarian researchers to field and laboratory techniques, fault-slip analysis expanded into the Pannonian Basin in Hungary and in some adjacent areas, and is still going on. This paper reviews the results achieved during this $\sim 35$ year time span from a historical perspective, by the compilation of the determined Cenozoic stress fields, their temporal boundaries, and uncertainties. The model for the evolution of the stress field became more complicated, and more and more details in the deformation history were realised, both in the Alcapa and Tisza-Dacia units of the Pannonian Basin. The integration of palaeomagnetic and stress data indicated that some changes in stress axes (and in fault orientation) are due to vertical-axis block rotation, and are not real rotation of the external stress field itself. With the development of new approaches, like tilt test, combination of surface and subsurface fault data, radiometric age determination of deformed rocks, fine separation of fracture sets can be achieved and the multiple recurrences of stress fields with identical principal axes were demonstrated. The refined methods permitted the demonstration of basin-wide inhomogeneity of the stress field for some phases. However, the precise timing, the number of phases, separation of events with similar stress axes, and the variability of the maximal stress axes of a given stress field remain the major questions to be solved in the future. Rheological conditions of the deforming media and physical parameters of the fracturing will be the other future steps in research, to be achieved by studies of deformation bands, fluid inclusions, isotopes, in order to better understand the connection of deformation, subsidence, diagenesis, and fluid flow. 


\section{Introduction - palaeostress and fault-slip analysis}

Palaeostress and fault-slip analysis depict the geometry, kinematics, and dynamics of brittle structures (faults, joints, veins, etc.) observed in natural or artificial outcrops. In fact, this systematic method replaced earlier directional measurements which were unable to find genetic connections between the observed fracture systems (e.g. BALÁSHÁZY 1977 in Hungary). The key to understand the mechanics of brittle deformation comes from the early works of ANDERSON (1905, 1942) followed by WALLACE (1951) and BotT (1959) which revealed the relationship of principal stress axes and faults, joints and dykes.

The field and analytical techniques were developed in the 1970s, mostly by French geologists. First, they solved the problem of the connection of the stress state of a point and the observed fault planes containing the striae by having established a simplified stress tensor which, as a second-order mathematical tensor, determines this functional relationship (CAREy \& Brunier 1974, Angelier 1979a). Behind the model of this simple mathematical function, researchers supposed the unequivocal connection of the observed striae and the shear stress component resolved on the fault plane; this is why that this line of research refers to stress axes and faults, and not to kinematic axes. Although this presumption was proved not to be universal (MAERTEN 2000), but it is reliably acceptable for most cases. The computed stress axes are numerically well-defined although inherently have uncertainties. Nevertheless, numerical methods better characterise the stress state of deformation, rather than, for example, the graphical solutions for faults and stress; this latter method gives only wide spatial domains for possible locations of the axes and does not issue the ratio of axes (ANGElier \& MECHLER 1977, AleXANDrowski 1985).

The first theoretical results were soon followed by the development of field measurement technique and computing methods (ANGELIER 1984, 1990), and the first interpretations of field studies (ANGELIER 1979b). This technique had later wide application in structural studies, while the determined stress regimes were extrapolated to large areas, sometimes to plates, and were used to characterise the structural evolution of plate boundaries and interiors (e.g. ANGELIER et al. 1986).

Several improvements and approaches were developed from these early years of research to recent times, and their complete list is beyond the scope of this contribution (NEMČOK \& LiSLE 1995, DELVAUX \& SPERNER 2003, YAMAJI et al. 2003, ŽAlOHAR \& VRABEC 2008 and GERNER 1990, SIPOS 2013 in Hungary). Separation of fracture sets into phases still remains problematic. The easiest solution is the manual separation, supported by calculations of separated fracture sets. Later, computer-assisted methods were developed (ANGELIER \& MANOUSSIS 1980), and recently included very sophisticated mathematic approaches (KeRnSTOCKOvÁ \& MeliCHAR 2009, SiPOS et al. 2018).

Another school of fault-slip analysis elaborated a parallel, although not completely separated line of research, which is using kinematic axes instead of stress axes (MARRET \& ALLMENDINGER 1990). The debate has not been closed (till some years ago) if the calculated axes can be named 'stress', 'kinematic' or 'strain' axes (MARRET \& PEACOCK 1999).

The stress and fault-slip analysis was used in Hungary from its very early stage of methodological development, starting with pioneer works of Francoise BERGERAT, Jacques GEYSSANT and Claude LEPVRIER (BERGERAT et al. 1983b, 1984a, b). Subsequent visits of F. BERGERAT, and the PhD studies of some of us in France (L. CsOnTOS, L. FodOR, L. BENKOVICS) helped to establish this method in Hungary, and later, in the whole Pannonian Basin. The goal of this contribution is to follow the evolution of knowledge on the palaeostress fields of the Pannonian Basin, which have implication on understanding of map-scale tectonic features. Although, this is a historical review, but sometimes I would try to draw modest conclusions on the results by formulating which seems to be (still) valid, where are the problems to be solved, and by giving estimations on future research directions. A secondary goal is to provide a fairly complete compilation of Hungarian publications dealing with palaeostress and fault-slip analysis; such list may help readers to use the appropriate works in their own research.

This summary is published in the memorial volume of Frank HoRvÁTH because he realised the importance of knowledge on recent and palaeostress fields. In the ISES project of the early 1990s, he strongly encouraged us to conduct such research, he invited us to conferences, involved us in international cooperation, particularly with the Vrije Universiteit, Amsterdam, which resulted in common publications, PhD thesis (e.g. BADA 1999). Our second summary of stress field (FODOR et al. 1999) issued from this international cooperation, and was definitely catalysed by Frank.

\section{Stress field data in time and by regions}

\section{Presentation of stress field data}

In this communication I compiled a table from most of works which presented palaeostress data (Figure 1).

Of course, such a compilation cannot be complete, my

\footnotetext{
$\rightarrow$ Figure 1. Stress axes and deformation phases in the Pannonian Basin. A) Results of the main summary studies, and data from parts of the Alcapa unit and from the Periadriatic and Mid-Hungarian Shear zones and their vicinity (southern Pannonian Basin in Croatia). B) Results of studies from the southwestern part of the Transdanubian Range. C) Results of studies from the NE part of the Transdanubian Range, northern Hungary and southernmost Slovakia. D) Results from studies in the Bükk Mts., Darnó zone, Aggtelek-Rudabánya Hills, and Tokaj Mts. E) Results of studies from the Tisza-Dacia unit. All data for Cenozoic deformation younger than Middle Eocene. Legend see Figure 1, E

$\rightarrow$ 1. ábra. Feszültségtengelyek és töréses deformációs fázisok a Pannon-medencében, magyar kutatók munkái alapján. A) A föösszefoglaló tanulmányok és a Periadriai-és Közép-magyarországizónákról szóló munkák eredményei. B) A Dunántúliközéphegység $D N y$-i részéról szóló tanulmányok eredményei. C) A Dunántúliközéphegység ÉK-i részéröl, Észak-Magyaroszágról és Dél-Szlovákiáról szóló tanulmányok eredményei. D) A Bükk, Darnó-zóna, Aggtelek-Rudabányai-hegység, a Tokaji-hegység feszültségadatai. E) A Tisza-Dacia-egység feszültségadatai. Csak a középsö-eocénnél fiatalabb fázisok kerültek ábrázolásra. Jelkulcs az ábra E részén
} 


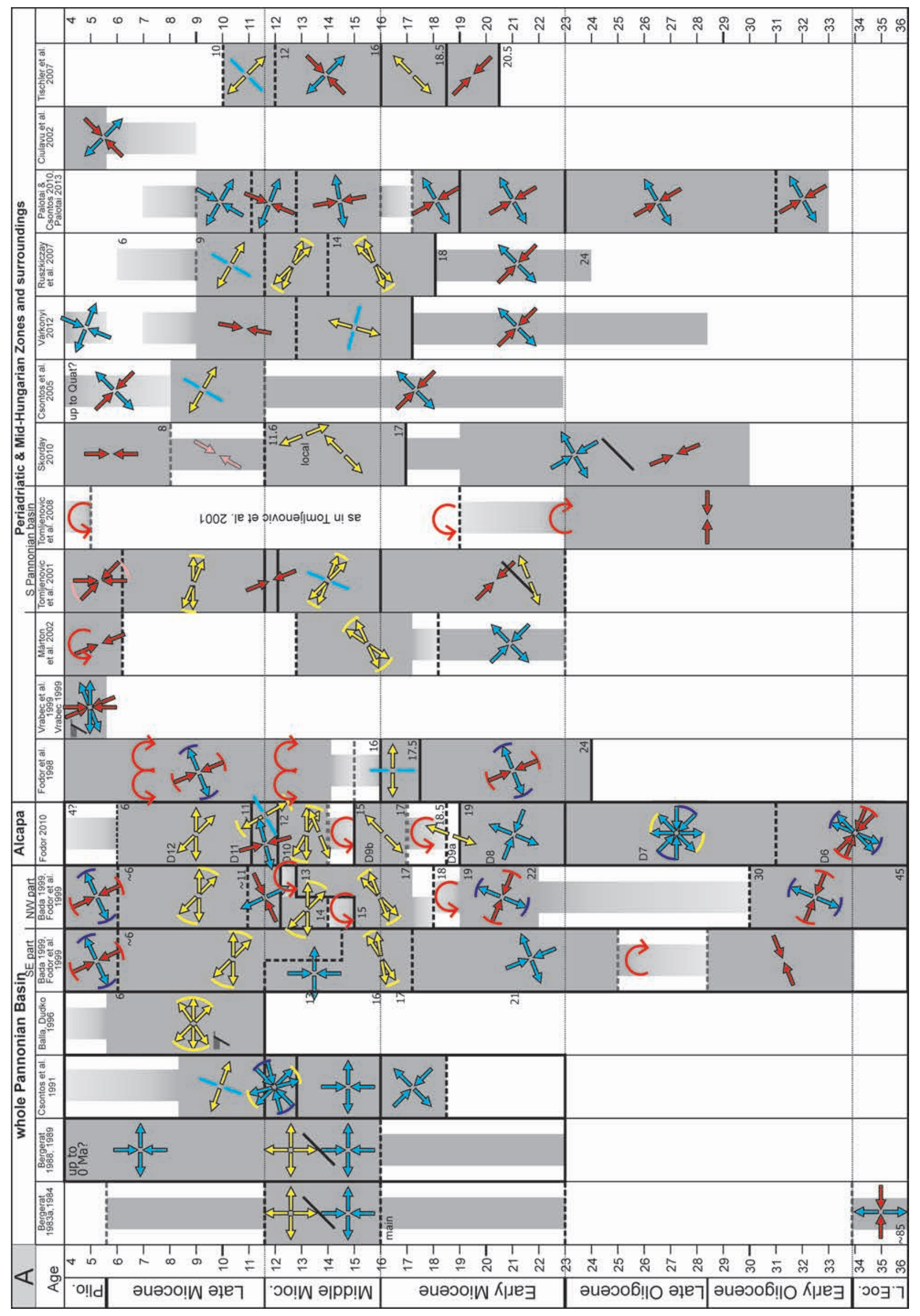




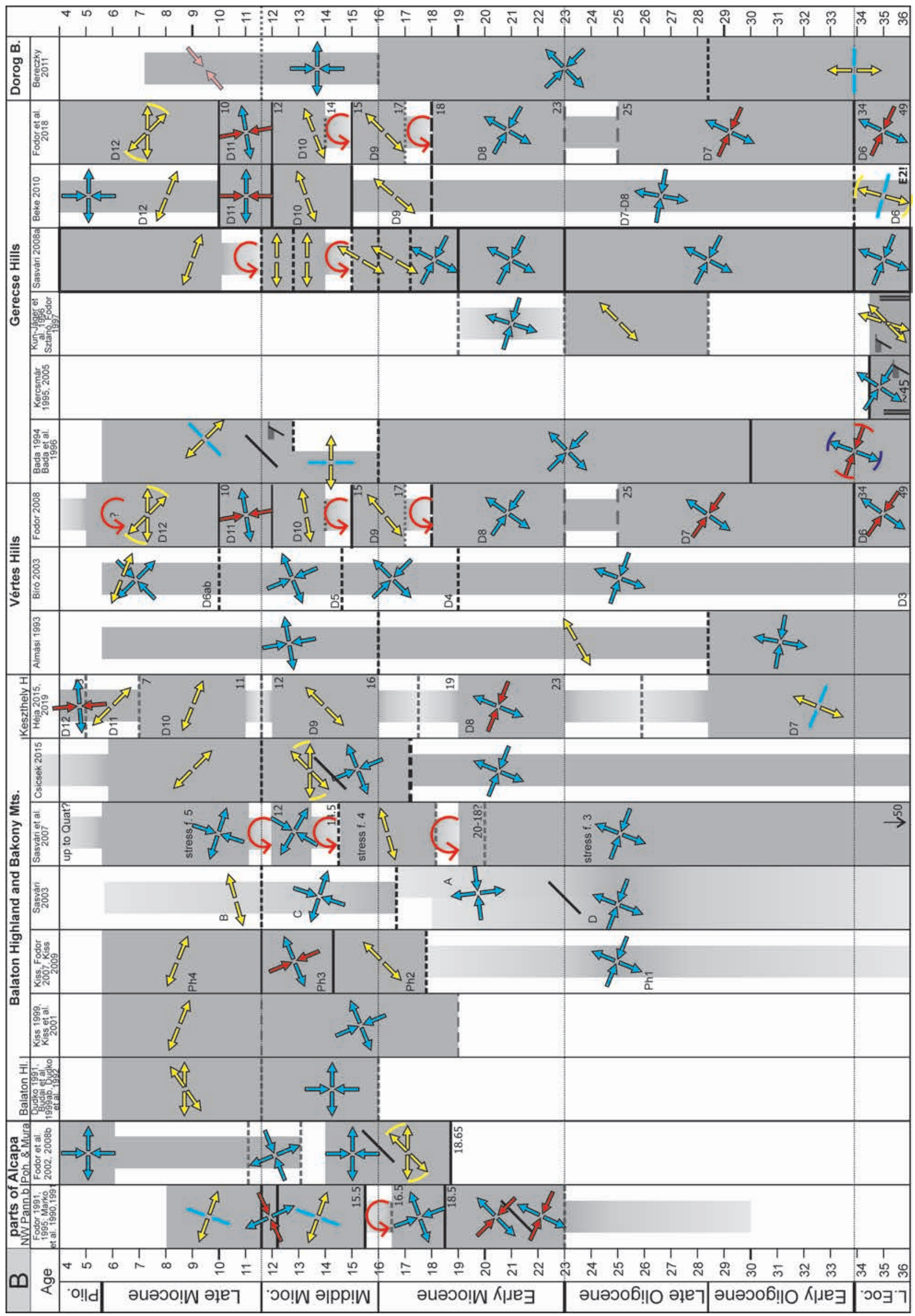




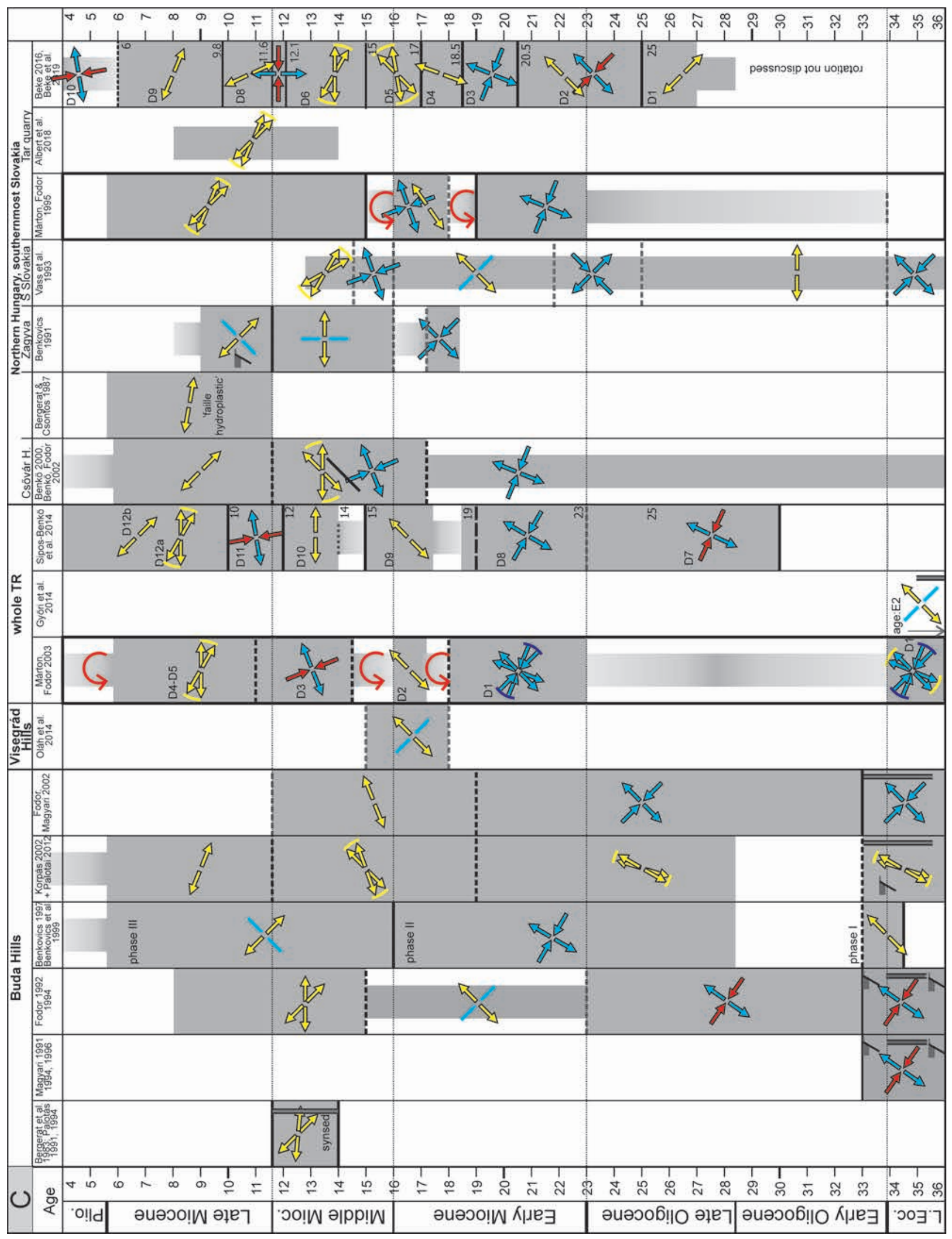




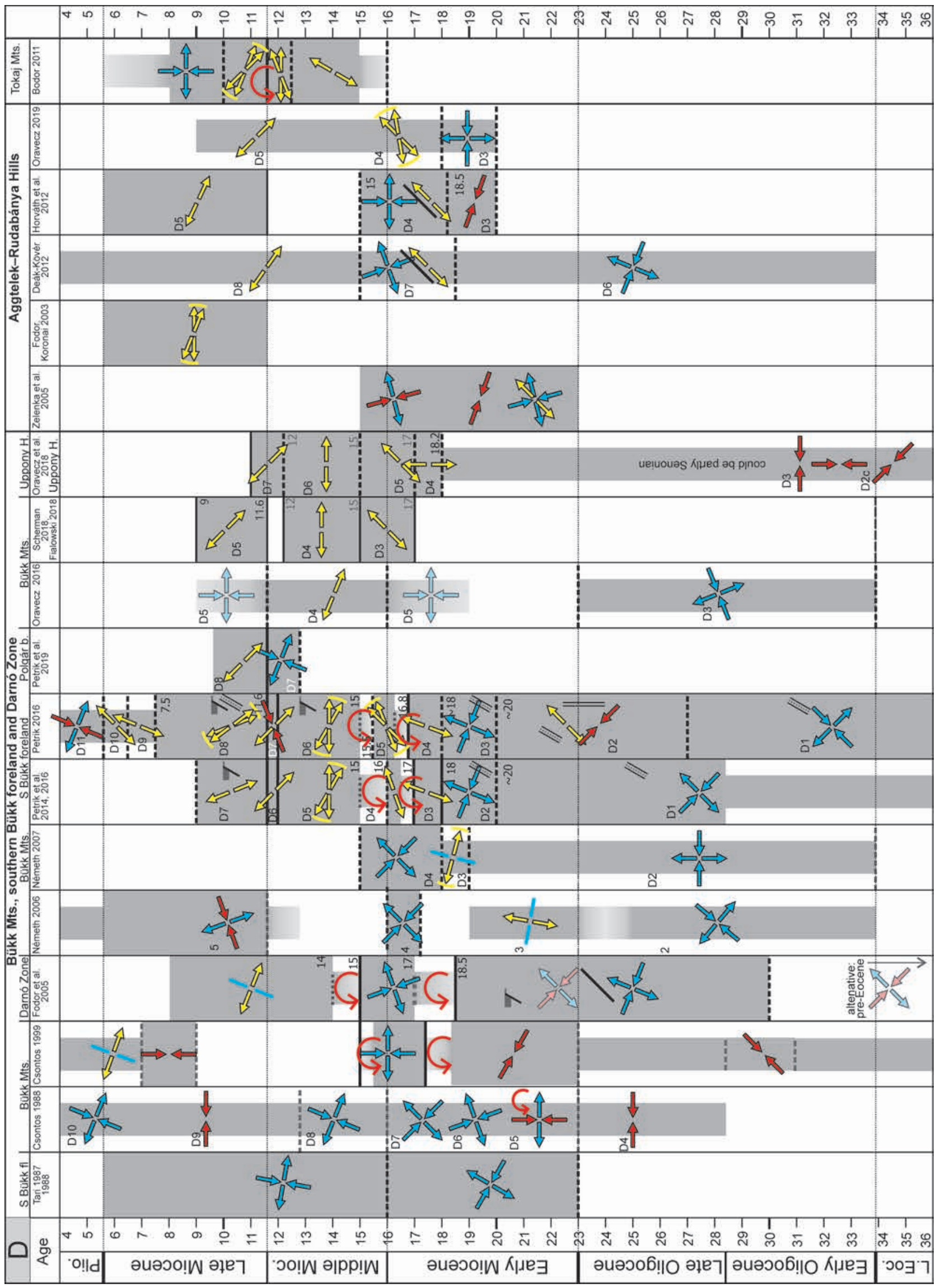




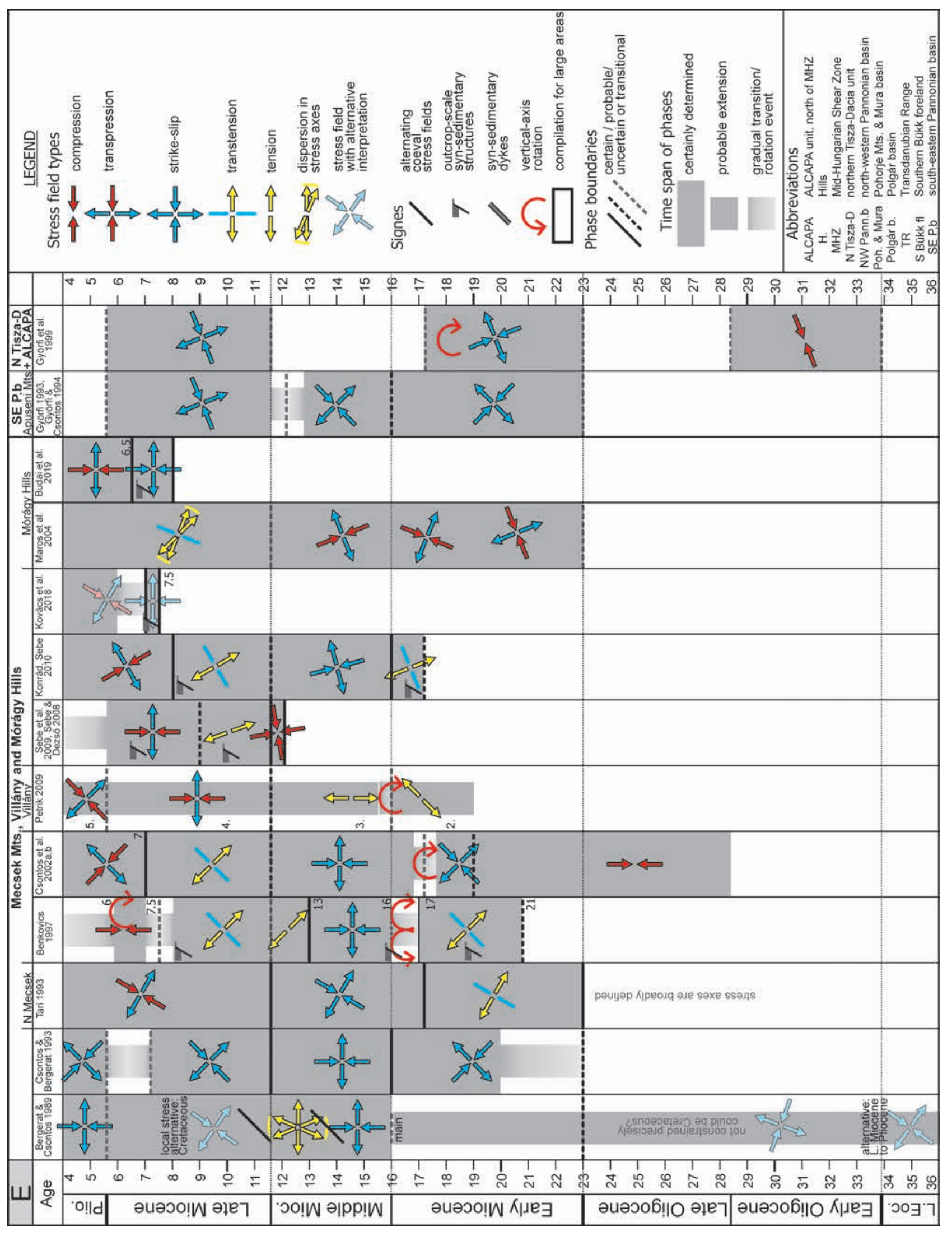


apologies for eventual deficiency. On the Figure 1 only postmiddle Eocene palaeostress data are presented, but in the text Mesozoic structural data are mentioned as well. I did not consider Quaternary data because their origin and timing can be debated and this topic in fact merits an independent publication. Figure 1 shows the palaeostress evolution, using the stress field types and very simplified and averaged stress axes, sometimes with dispersion ranges of axial directions, sometimes with two main directions. Several works could be unified and reported by one set of signs.

I classified the structural phase boundaries (change between stress fields) given in publications as being certain, probable, or uncertain; the latter two cases are applied when the timing was not clearly formulated, when it remained poorly constrained by the original data, or simply when I did not get the message from the work. For clearly identifiable stratigraphic boundaries I used the presently accepted numerical ages (Geological Time Scale 2016 and for some Paratethys stages, SANT et al. 2017). When phase boundaries were not precisely formulated or there seems to be discrepancy between the text and figures an arbitrary boundary is presented.

Grey background shading indicates suggested temporal extension of a given phase, when I (subjectively) considered data less convincing, only narrow columns are used. Narrow columns with transitional grey shading indicate uncertainties due to lack of precise time constraints or when transition from one stress field to the other seems to be gradual. Time spans of rotations are also indicated in this way, mostly because registered stress axes should change continuously during such deformation, so a sharp boundary is difficult to set up. Specific signs for the types of structures (e.g. synsedimentary faults and dykes) are given. Spatially variable stress field is difficult to visualise, but I tried to indicate coeval stress axes.

Publications and Master or $\mathrm{PhD}$ theses are listed approximately chronologically. However, this rule has been changed in order to juxtapose spatially closely related results. This spatial distribution led to juxtaposition of works from different regions of the Alcapa unit (Figure 1, B-D); these are the Transdanubian Range (TR, subdivided into BakonyBalaton Highland, Vértes, Gerecse, and Buda Hills), northern Hungary (between the Buda Hills and Darnó Zone) and NE Hungary (Darnó Zone, the Bükk Mts. and the AggtelekRudabánya Hills and the Tokaj Mts.). Within these areas I try to present the data in one direction (generally from SW to NE). Some studies about the Periadriatic Fault and Mid-Hungarian Shear Zone are also shown where stress axes were determined or inferred (Figure 1, A). Because of the Miocene rotation history is different in the two main units of the country (Alcapa and Tisza-Dacia), data from the Mecsek-Villány area, and from the south-eastern Pannonian Basin are shown and described separately (Figure 1, E). I will mostly concentrate on data from Hungary, and marginal parts of the Pannonian Basin will only occasionally be mentioned.

I will not always refer to this figure in the text, it would lead to very frequent citation. In most cases, the text will not describe the complete stress field evolution of the cited author (the figure should do this), but I may subjectively emphasise the most important recognition(s).

\section{Fault mapping and kinematics without the palaeostress approach}

Before going into details of palaeostress analyses, I mention the older approach which dealt with mapping of faults and sometimes also with the determination of their kinematics. In fact, most maps showing fault systems could be mentioned here although the often rectilinear geometry, orthogonal fault orientation, and other aspects of fault presentation can strongly be criticised. Among the researchers who influenced positively the fault analysis of Hungary, J. MÉsZÁROS is to be mentioned first, who described systematically dextral strike-slip fault system in the Bakony Mts. which is still basically valid (MÉSZÁros 1982, 1983). The works of Balla (1984, 1988a, b) and BALla \& DudKo (1989) gave a coherent evolutionary scheme for the Pannonian Basin structures, and are of very large importance; in fact, these works influenced our thinking since the time of publications. Although they did formulate their results in fault geometry, kinematics, and timing, it would be possible to convert the conclusion into stress data. A great number of publications have significant data on the brittle structural evolution of the Pannonian Basin, both from subsurface data sets, and from maps (BREZSNYÁNYSZKY \& HAAS 1990, BREZSNYÁNYSZKY \& SíKHEGYI 1987; FÜlÖP 1990; JASKó 1988, 1989; HORVÁTH 1990, 1995; HORVÁTH \& RUMPLER 1984; ROYDEN \& HORVÁTH 1988; HORVÁTH \& TARI 1999; TARI et al. 1992, 1999; CSONTOS 1995; DETZKY-LÓRINCZ et al. 2002; HAAS et al. 2010; TARI \& HORVÁTH 2010; HoRVÁTH et al. 2015) but this work will concentrates only on those ones which have an approach of palaeostress and fault-slip analysis. All works dealing with the origin, evolution, and geometry of the faults in the Pannonian Basin will not be referred, despite their tremendous contributions to the topic of faults.

\section{Early structural observations-close to the palaeostress conception}

An interesting precursor work was published by BOKOR (1939). He was aware of the relation of Mohr fractures, shear stress, stress ellipsoid and "deformation axes". He measured joints in the Buda Hills, and suggested N-S compression. However, he considered all fractures with strike-slip character, an error which led him in a dubious estimation of stress axes.

Another approach tried to find the "pair of compressional forces", which can be considered as a precursor of compression in modern palaeostress terminology, although the physical basis was not clearly presented (and maybe not understood). In this line, BALKAY (1960) estimated NW-SE directed such "forces" in the northern Bükk Mts. This work, and, among many others, one of TOMOR-THIRRING (1936) and ZELENKA (1975) represent examples of outcrop-scale structural observations, although still far from modern faultslip analysis. 
In the Transdanubian Range Maros $(1986,1988)$ carried out modern fault mapping and outcrop-scale kinematic observations without using sophisticated computer techniques; his kinematic observations were valuable (e.g. strike-slip character of the Vértessomló Line), but comparison with modern stress data is not easy due to lack of timing of the phases (this is the reason it is not shown on Figure 1, $A-E$ ). TARI (1991) also used the information on kinematics of some dextral faults, and established his model on the rotation of these faults, although stress axes were not deduced from his analyses.

\section{Results of early palaeostress studies (1982-1991)}

The first modern fault-slip measurements of BERGERAT, GEYSSANT and LEPVRIER and the subsequent palaeostress calculations were completed in 1982-1984 and were mainly done on Mesozoic rocks, where fault-slip observations are much easier than on Cenozoic rocks. The first results suggested multidirectional extension, connected to, or alternating with, strike-slip regime (BERGERAT et al. 1983b, 1984a, b) (Figure 1, A). Pre-Miocene E-W compression was also recognised but with poor time constraints. Syn-sedimentary late Badenian to Sarmatian extension was also documented in the Buda Hills (Figure 1, C) (BERGERAT et al. 1983a).

In the first basin-wide summary of fault-slip data BERGERAT $(1988,1989)$ suggested the alternation of strikeslip regime with $\mathrm{E}-\mathrm{W}$ tension and locally developed $\mathrm{N}-\mathrm{S}$ (graphically NNW-SSE and NNE-SSW) tension through the whole Miocene and Pliocene. In her model extensional deformation developed between important strike-slip zones. This model was partly based on field works in the MecsekVillány area (BERGERAT \& CSONTOS 1988).

The effect of this methodological know-how is clearly visible on the parallel structural analysis and mapping of the Bükk Mts. which, in addition to valuable fault kinematic data within the mountains, led to the first sketchy fault-slip analysis of the Bükk Mts. and their southern foreland (Figure 1, D). Csontos (1988) in his first work separated six Cenozoic deformation phases and attributed a number of ductile structures to these events. Later he revised the timing of phases (CsONTOS 1999) and he incorporated the verticalaxis rotations to explain changes in the stress axes. At the same time of the early analysis in the Bükk, TARI (1987, 1988) conducted a pioneer work in the southern foreland (Vatta-Maklár trough) analysing seismic reflection profiles, and comparing the derived fault pattern to surface fault-slip data. He established the strike-slip origin of this basin. A small study of few outcrops of Miocene coal and lignite documented roughly $\mathrm{E}-\mathrm{W}$ tension governing "hydroplastic faults" (Figure 1, D) (BERGERAT \& CSONTOS 1987).

In the meantime, the author of this contribution completed his $\mathrm{PhD}$ work on the Vienna and satellite basins in the north-western part of the Pannonian Basin system, and it was one of the first detailed studies of a small region (Figure 1, A), (FodOR 1991, 1995; FodOR et al. 1990; MARKO et al. 1990,
1991). In these works, clear clockwise change in stress field appeared, from Oligocene to end-Sarmatian, and a counterclockwise change, back to ESE-WNW extension, after the Sarmatian. As a local synthesis, MARKO et al. (1995) summarised fault-slip and stress field data for the Slovakian part of the Vienna and surrounding Miocene basins.

All these works led to the second synthesis of observations and analyses on palaeostress fields of the entire Pannonian Basin (Csontos et al. 1991) (Figure 1, A). This work emphasised the clockwise change in the palaeostress axes through the Miocene, and connected this change to the temporally varying deformations in the external flysch belt of the Carpathians. Although we mainly referred to the 'orogenic vectors' of JIǨí̌̌̌K (1979), a term uncertain in nature, our main result probably was to establish the connection of deformation events at the front of the Carpathian orogen and inside the hinterland (Pannonian back-arc basin). In several of our works published in those years we clearly recognised the close temporal connections of the changing palaeostress axes and gradual shift of the main external thrusting along the Carpathian front (FoDOR et al. 1990, Csontos et al. 1991, FODOR 1995, FODOR \& CsONTOS 1998).

\section{Results of palaeostress studies from 1991 to 1999}

Following these early years, during the 1990s several works concentrated in small areas, and have issued precisions for the general stress field evolution or found local features. They were mostly MSc theses, but their conclusions seem to be well-based on the newly learnt technique.

In the Balaton Highland and southern Bakony Mts., during the geological mapping work DUDKO (1991), DUDKO et al. (1992) and BUDAI et al. (1999a, b) described the observed brittle structures, comprising Cretaceous thrusts and folds, and Miocene strike-slip versus extensional basin formation phases (Figure 1, B).

In the Gánt quarries of the Vértes Hills AlmásI (1993) confirmed the same Eocene to Oligocene stress field as has been documented in the Buda Hills. He was the first to realise the very local stress field inhomogeneity around fault oversteps; an idea explored later in detail by FODOR (2007). The recognised E-W trending strike-slip faults are similar to those ones found by GYALOG (1992) in the close vicinity.

In the Gerecse Hills, BADA (1994) collected a great number of data and separated 7 phases, three of them being Mesozoic in age (BADA et al. 1996). Although recent summary (FODOR et al. 2018) seems to refine the stress field evolution, and may change the age of some measured faults from Miocene to Mesozoic, the recognised stress fields are valid. KUN-JÁGER et al. (1996) recognised not only the tensional stress fields but also the geometry of syn-rift faults within the central Gerecse, most of their remarks became verified during later works (MURÁTI 1997, ÁdÁm et al. 2001, compare also with FODOR et al. 2018). LANTOS (1995, 1997) and KerCSMÁr (1995) estimated Jurassic and Eocene stress fields from sedimentary dykes 
and other syn-sedimentary structures; these results were extended later (LANTOS 2004 and KERCSMÁR 2005, KERCSMÁR \& FODOR 2005). SZTANÓ \& FODOR (1997) demonstrated Late Eocene extensional stress field and a younger (Eggenburgian?) strike-slip type field with similar $\rho_{3}$ axis, in a later disappeared northern Gerecse road cut (Nyergesújfalu).

In the Buda Hills MAgYARI (1991, 1994, 1996, 1998) extended our knowledge on the Eocene deformation, determining (E)SE-(W)NW compression and perpendicular tension and placed the deformation in the context of the overview work of FODOR et al. $(1992,1994)$ (Figure 1, C). These latter ones extended the Eocene stress field into the Oligocene and early Miocene based on deformed Eocene rocks, and also on the palaeogeographic evolution of the Buda Hills. BALLA \& DUDKO (1990) observed SSE vergent folds in the Oligocene, what they dated as Miocene; this could fit into the stress history described above. The compressional-transpressional origin of the Buda Hills is in agreement with the model of TARI et al. (1993) based on large-scale geodynamic interpretation and subsidence data. PALOTÁs $(1991,1994)$ completed the knowledge on the Sarmatian syn-sedimentary deformation of the Tétény plateau already observed by BERGERAT et al. (1983a). Benkovics (1997) and Benkovics et al. (1999) recognised E-W trending dextral shear zones, similar to those observed by Fodor et al. (1994) and MAGYARI (1996).

In NE Hungary, BenKovics (1991) characterised the Zagyva graben as marked by ESE-WNW extension, and he realised several deformation episodes with similar or slightly changing stress axes (Figure 1, C). He also found a still enigmatic stress field with E-W horizontal $\sigma_{1}$ axis, similar to the findings of NEMČOK et al. (1989) and FODOR et al. (1990) in the Vienna Basin. Just north from this graben system, in southernmost Slovakia, palaeostress determinations resulted in six pre-Pliocene phases with strike-slip, transtensional or extensional character (VASS et al. 1993). An alternative interpretation of phase boundaries were later presented in the work of FODOR et al. (1999), mostly based on data of a common field trip with Slovak colleagues.

\section{Methodological advance — palaeomagnetism and palaeostress}

Palaeomagnetic data revealing vertical-axis rotations were soon compared to stress data; probably the idea first occurred in CsONTOS (1988), FodOR \& MARKO (1990), and FODOR et al. (1990) while TARI (1991) used kinematic data to infer rotations. In the preliminary work of FODOR (1991, 1995), and in the first study directly comparing stress and palaeomagnetic sites, MÁRTON \& FODOR (1995) concluded that the (1) two phases of vertical-axis rotations and two changes in the maximal horizontal stress axis occurred during the Miocene, (2) the block rotation happened in opposite direction with respect to changes of the stress axes (counterclockwise and clockwise, respectively), and (3) the two phenomena were coeval within the precision of time constraints. This correlation strongly suggests that most of the changes in the direction of the stress axes were apparent and only due to the physical rotation of rocks. This conclusion inspired most subsequent works, and was later extended to the Transdanubian Range (MÁRTON \& FODOR 2003), to the Mecsek Mts. (BenKovics 1997; CsOnTOS et al. 2002a, b, Maros et al. 2004), to Medvednica Mts. (Tomljenović et al. 2008), and embedded in syntheses about the whole Pannonian Basin (FoDOR et al. 1999).

\section{Large summaries}

BALLA \& DUDKo (1996) collected a great number of data (mostly from other authors) on the fracture sets displacing Pannonian strata. They accepted the stress estimations or calculations of the original authors, and compiled the first detailed map representing stress data from the Hungarian part of the Pannonian Basin (Figure 1, A). The data set reflects heterogeneous tensional axes, ranging from NE-SW to SE-NW, with mean and frequent $\mathrm{E}-\mathrm{W}$ direction. However, it is not a complete presentation of Late Miocene stress field because most fractures of that age are present in older rocks.

All these early works led to the third basin-wide summary of palaeostress data (FODOR et al. 1999). In this work, we confirmed for the Alcapa unit the clockwise rotation of palaeostress axes from the early Miocene to the end of Sarmatian, and afterward a change of stress axes in counterclockwise direction. This summary already integrated the conclusions of coordinated palaeomagnetic and fault-slip studies, and demonstrated that the change in palaeostress axes are apparent and are mostly (but not totally) due to vertical-axis rotations. This is the reason that apparent change in stress axes were opposite in the northern versus the southern Pannonian units (Alcapa versus Tisza-Dacia). The palaeostress data were used in a semi-quantitative tectonic reconstruction of the entire Pannonian-Carpathian region depicting the geometry of fault patterns and the dynamic background of deformations. The stress trajectories were restored by averaged palaeomagnetic data, and they were projected on a qualitative reconstruction which took into account earlier tectonic reconstructions, like those of BALla (1984, 1988a, b), TARI (1994) and TARI et al. (1995). The work of BADA (1999) largely contributed to this synthesis, in fact he compiled the database in digital format and solved the presentation of the stress axes. He also prepared finite element computer models for the stress field evolution and emphasised the role of slab rollback, topography, and Adria push which altogether led to the rifting of the Pannonian Basin.

\section{Palaeostress studies between 2000 and 2010 \\ Methodological advances - seismic profiles, maps}

Already from the 1990s but mainly during the 2000s seismic reflection data were improved considerably. This development has facilitated a more detailed imaging and thus deeper understanding of the fault pattern, not only 
along $2 \mathrm{D}$ sections but now in $3 \mathrm{D}$ data sets. This technique provides unprecedented tools to image fault patterns, but the question arises if fault kinematics could also be determined. The answer depends on the case. Some aspects of fault kinematics can be deduced from seismic data but not (or rarely) the complete slip vector. The complete fault pattern permits the deduction of the principal stress directions a generalised to the entire study area but stress determination in individual points are not possible. The early studies in this line mostly depicted fault kinematics and fault patterns in sub-basins (e.g. PoGÁCSÁs et al. 1989, 1994). For the point of view of palaeostresses a combination of data sets, namely surface fault-slip data and seismic profiles can give good results. The work of TARI $(1987,1988)$ and of BENKOVICS (1991) already benefitted from this combined approach. Other works, namely WóRum (1999) and CsonTOS et al. (2002a, b), also used this combination in the Mecsek area. CsONTOS et al. (2005) suggested fault kinematics from fault patterns derived from seismic data sets. Limited amount of seismic data was also used for the Darnó Line (FoDOR et al. 2005). Probably the largest quantitatively balanced subsurface and surface datasets were provided by PETRIK (2016).

The combination of data on the outcrop- and map-scale fault patterns improved the geological maps considerably but, as a reaction, also contributed to the understanding of the stress field evolution. The first of such works were the maps of the Bükk Mts. (CsONTOS 1988) and of the northern Vértes (MAROs 1986, 1988) as I mentioned earlier. The first of such printed map was that of the Balaton Highland (BUDAI et al. 1999b) but the large fault-slip dataset of DUDKO (1991) was not presented in detail and only partially embedded in the explanatory booklet (BUDAI et al. 1999a). This slight deficiency was completed in the northern TR (DUDKO et al. 2000) and in the Vértes Hills, where fully presented fault-slip data were completely taken into account during the compilation of the map itself (FODOR et al. 2008a). The other advancement of these two last maps that they showed with different symbols both the age and kinematics of the faults.

In addition to Cretaceous elements, the map of DUDKO et al. (2000) separated Palaeogene, late Eggenburgian-Sarmatian and late Miocene-Pliocene phases, while the map of FODOR et al. (2008) shows the faults of the same number of Cenozoic phases with slightly different temporal boundaries. DuDKo et al. (2000) defined a great number of faults mostly matching more detailed maps (e.g. BUDAI et al. 2018) although the rectilinear fault traces seem to be a simplification. The dextral character of the Vértessomló-Nagykovácsi and normal slip on NW-SE striking faults are still held valid.

\section{Palaeostress studies in the Alcapa unit}

Case studies continued from 1999 to recent years increasing considerably our knowledge on fault pattern and deduced stress fields. In the western-south-western margin of the Pannonian Basin in northern Slovenia FodOR et al. (2002, 2008b) demonstrated E-W to NE-SW extension, both in ductile and brittle deformation styles; these structures formed during the syn-rift phase of the Pannonian Basin (Figure 1, A). This phase was overprinted by NE-SW compression and transpression with $\mathrm{N}-\mathrm{S}$ compression, this latter being the neotectonic deformation.

In the Bakony Hills ALBERT (2000) analysed two sets of Mesozoic folds and these data could be transformed to sub-perpendicular contractional directions. KISS (1999, 2009) and KISS et al. (2001) described Miocene extension in the Bakony Mts. and demonstrated the presence of transpressional fault zones around Csesznek and in the northern Bakony as well (KISS \& FODOR 2007). SASVÁRI (2003) established 4-6 stress fields in the surroundings of the Telegdi Roth line, although Miocene sinistral character of the fault does not match the view of KISS (1999, 2009). In a revised work SASVÁRI et al. (2007) emphasised Eocene to early Miocene dextral slip of the fault, while the subsequent evolution was similar to other's results. At the same time, PAlOTAi et al. (2006a, b) investigated fault pattern and potential kinematics of two important outcrops in the TR, on the Eperkés Hill, the other in the Pilis Hills. In both cases they confirmed redeposited blocks of older rocks into Late Jurassic matrix; the triggering faults would be extensional or thrust faults with their preference for the latter solution.

In the Vértes Hills FODOR (2008) prepared an extensive work where 13 Mesozoic to Quaternary brittle deformation phases were presented. The elaborated evolutionary scheme was later used in several works (e.g. FODOR 2010, FoDOR et al. 2018), the Cenozoic phases being named D6-D13. The compilation of structural data was based on earlier results (BÍ́Ó 2003, FODOR \& Bíró 2004, BudAI et al. 2005, BENKŐ 2005 , etc.) and on an early version of digital map with real tectonic data base behind (Ко́тA 2001) and embedded in a detailed mapping program (BUDAI et al. 2008, FoDOR et al. 2008a).

Parallel to the mapping work in the Vértes Hills, in the neighbouring Gerecse Hills the works of SASVÁRI (2008b, 2009a, b ) demonstrated a number of brittle structures and also folds, mostly considered as Mesozoic in age. He made a summary of the then available stress data, and this was the first of such detailed compilation for the entire TR (SASVÁRI 2008a). In this work, he reviewed the stress fields stage by stage, thus easy recognition of deformation phases is somewhat hampered by this approach. .

Still in the Gerecse Hills BEKE (2010) found several dykes, faults of Middle Eocene age with NNE-SSW to NESW tension. The new data, together with revision of earlier measurements, extended some phases of FODOR (2008), particularly D11 transpressional deformation, into the Gerecse. HorÁNYI et al. (2010) determined ESE-WNW Jurassic extension having created small dykes and syn-sedimentary grabens, followed by early Cretaceous tilt in the same direction.

In the Buda Hills KorPÁs et al. (2002) and FodOR \& MAGYARI (2002) provided additional arguments for synsedimentary Eocene and post-sedimentary younger de- 
formations (Figure 1, C). Interestingly, KoRPÁs et al. (2002) did not find the otherwise ubiquitous strike-slip deformation of (late) Oligocene to Eggenburgian age. They suggested that the eastern boundary fault zone of the Gellért Hill was probably active already in the Palaeogene but certainly during several Miocene phases; also supported by observations of PALOTAI et al. (2012) from below the Danube. GÁL et al. (2008) studied WNW-trending chalcedony and NNWtrending barite veins and connected their formation to the late Early Oligocene and to the Middle Miocene stress fields, respectively. In the easternmost outcrop of the TR, in the Csóvár Hills BENKó (2000) and BENKÓ \& FODOR (2002) demonstrated N-S Cretaceous contraction (Figure 1, C), and several Cenozoic deformation phases, in agreement with earlier measurements of F. BERGERAT and L. CsONTOS (unpublished, incorporated in FoDOR et al. 1999).

In the comparative study of palaeomagnetic and stress data carried out in the entire TR MÁRTON \& FODOR (2003) defined 4 stress fields, strike-slip faulting before rifting, the main rifting event, and late Badenian to earliest Late Miocene transpression, followed by post-rift extension (Figure 1, B). Two of the rotation phases were correlated to the changes between the principal stress axes, like it was suggested in northern Hungary. However, changes in stress axes and correlative rotations were smaller than in north-eastern Hungary.

In north-eastern Hungary, several works concentrated on deformations of Mesozoic rocks. Because the deformation style is mostly ductile, and the deformation mechanism is partly crystalplastic, these studies often dealt with shortening rather than compressional directions. However, because brittle and crystalplastic structures are sometimes mixed and brittle deformation phases were also presented, these works are also mentioned in this compilation (Figure 1, D). In the Bükk Mts. FoRIÁN-SZABÓ (2001) and FoRIÁN-SZABÓ \& CSONTOS (2002) assumed the south-eastern vergency of the Kis-fennsík nappe due to NW-SE compression. This major phase, and several previous and successive folding phases could happen in the Cretaceous. KoroKNAI (2004) dealt with the Cretaceous ductile structures of the Uppony and Szendrô Hills and could determine shortening directions and northern vergency. NÉMETH \& MÁDAI $(2003,2004)$ and NÉMETH (2005) also focused on ductile (mostly crystalplastic) deformation of the Bükk Mts. and determined the temperature condition of folding. However, NÉMETH (2005) reported brittle faults belonging to several Cenozoic phases. In the eastern part of the Bükk Mts., and in a small southern Bükk area NÉMETH (2006, 2007, respectively) described one pre-Late Eocene N-S shortening, and three to four younger stress fields. While two of these stress fields correlate with those reported by MÁRTON \& FODOR (1995), the latest field, related to the uplift of the mountains, differs significantly from those reported from the surrounding basin area with its compressional or strike-slip type.

In the Aggtelek Hills HIPS (2001) followed the earlier work of CsONTOS \& HIPS (1997), analysed the considerably folded Lower Triassic rocks and suggested three shortening phases with NW-SE, N-S and NE-SW shortening directions (Figure 1, D).
Based on previously unpublished data of BERGERAT, CsONTOS and FODOR (1988-1991), FODOR et al. (2005) reconstructed the stress field evolution of the Darnó Zone. The established 3 phases, and the intervening two rotations are similar to those having been suggested by MÁRTON \& FODOR (1995). FODOR et al. (2005) was not able to decide if a forth stress field, a NW-SE compression was a Cenozoic or older phase; this problem has been clarified by ORAVECZ et al. (2018).

More to the north, in the Rudabánya Hills few works led to similar results within or in the vicinity of the northern segment of the Darnó Zone (Figure 1, D). ZELENKA et al. (2005) connected the formation of an anhydrite dome to strike-slip opening, compression and then transpression during the Early Miocene; although the time constraints for the suggested phases are not the best. The last event, the post-early Badenian ESE-WNW extension was confirmed by FODOR \& KOROKNAI (2003) in few outcrops of the northernmost tip of the zone, partly based on displaced Pannonian sediments.

In the Aggtelek Hills HIPS (2001), following the earlier work of CsONTOS \& HiPs (1997), analysed the considerably folded Lower Triassic rocks and suggested three shortening phases with NW-SE, N-S and NE-SW shortening directions (Figure 1, D).

In the Tokaj Mts. Bodor (2011) documented detailed stress field evolution within the middle Miocene and early Late Miocene. The established clockwise change in the stress axes is at odds with the already stable stress directions in other parts of the Pannonian Basin. A local young block rotation near the middle to Late Miocene boundary explains one of the $\mathrm{CW}$ changes in principal stress directions. In fact, such young block rotation has been documented both in the Hungarian and Slovak side of the area (MÁRTON \& PÉCSKAY 1995, ORLICKY 1995). These results followed older measurements of BERGERAT \& FODOR (1988) and GYÖRFI (1994$1995)$ with preliminary interpretation of BADA (1995) which remained unpublished but incorporated in FODOR et al. (1999). The established phases can be reconciled with numerous earlier studies of the Tokaj Mts., which mostly observed the direction of magmatic dykes, volcanotectonic lines, and faults, all in roughly NW-SE, N-S and NE-SW orientation (MoLNÁr \& ZelENKA 1995; ZelenKA \& HoRvátH 2009). SASVÁRI \& KONDELA (2009) observed a number of striated faults along mineralised veins and reconstructed at least two stress fields, an ENE-WSW extension and a transtensional field with SE-NW extension. Extensive $\mathrm{K}-\mathrm{Ar}$ data sets constraint the volcanism and mineralisation between ca. 15 and 9.5 Ma (PÉCSKAY \& Molnár 2002), but the combined interpretation of dyke orientation, volcano-tectonic features and fault-slip data is still to be done in the future.

\section{Summary for the Alcapa unit}

Most of these works contributed to the fourth summary of palaeostress data although this summary was not complete and not extended to areas located south of the MidHungarian Zone (Figure 1, A). In my unpublished theses 
(FoDOR 2010) I described the thirteen post-Triassic phases, already shown in FODOR (2008), using an approach which combined most of the mentioned methods. I strengthened the idea of Miocene clockwise change of maximal horizontal stress axes, and the vertical-axis rotation as the cause of such apparent change. I also elaborated more detailed chronology of the phases ( 8 of Cenozoic) using tilt test, seismic and other geophysical data, preliminary information from deformation bands, etc. It turned out that during some phases (e.g. D10-D11) the stress field was markedly different in the western and north-eastern part of the Pannonian Basin, north-west from the MHZ.

\section{Studies after 2010}

Methodological advances — mineral veins, tilt test, AMS, deformation bands

The complexity of the fault-slip and palaeostress analysis as a method expanded during the last decade. Mapping, tilt test, usage of seismic data, study of deformation bands, precise dating of deformed magmatic rocks, all contributed to elaborate a more detailed brittle structural evolution than achieved by previous works.

One of the possible expansion of the fault-slip analyses could involve the study of mineral veins and their fluid inclusions. In the central TR (Velence Hills) BENKó et al. (2008, 2014a, b) used fluid inclusion planes to derive the direction of fault acting during inclusion formation; fluctuating extension in NW-SE to NE-SW were deciphered from such data (Figure 1, B) and Triassic age was suggested from K-Ar geochronological data. GYőRI et al. (2014) combined petrographic, isotope and fault-slip data to determine Campanian(?) and Eocene ages of red calcite veins of NNE-SSW and NW-SE striking sets occurring across the entire TR (Figure 1, B). The first group of calcites was already interpreted as reflecting a local tensional stress field during Senonian compression by KERCSMÁR (2004).

Tilt test was progressively recognized as an important tool in the relative and absolute chronological determinations of fault sets. One of the pioneer works in the Pannonian Basin was that of KISS et al. (2001), and later this became part of the routine analysis. Probably the most detailed elaboration was by FodOR (2008) in the Vértes, FodOR et al. (2005) in the Darnó zone, Petrik et al. $(2014,2016)$ and PETRIK (2016) in the southern Bükk foreland. Fracture sets formed before the tilt of a given formation should form in an early phase of deformation. When the tilting is Cretaceous, like in the TR, the pre-tilt fractures are older than the main folding phase of the range (latest Aptian to early Albian). In this way, Triassic faults were recognised in the Keszthely Hills (HÉJA 2015, HÉJA et al. 2018).

The combination of fault-slip and palaeomagnetic data made also a progress integrating anisotropy of magnetic susceptibility (AMS) data. SIPOS-BENKŐ et al. (2014) used AMS data to infer early stage deformation and compare AMS and stress axes within the TR. AMS axes shows good correlation with one of the earliest stress axes, thus it has been proved to be successful measure for deformation in sediments. This Pannonian results confirm the validity of this application described in other Mediterranean areas (CIFELLI et al. 2005). SiPOs et al. (2018) went further and, with the help of a new approach (SIPOS 2013), established the connection of Miocene AMS and stress axes in the western-southwestern margin of the Pannonian Basin in northern Slovenia. In this study the tilt test was routinely applied for both the AMS and fault-slip data and only pre-tilt data were compared.

During the last decade the importance of deformation bands (DBs) were progressively recognised in the brittle structural analysis (FoSSEN et al. 2007) and the same happened also in Hungary (BEKE \& FoDOR 2014, APRó et al. 2014). These strain-localisation structures are important, because they register, with unprecedented details, the evolution of the fracture system. It is mainly due to the fact that, although macroscopically similar, different DBs can be separated using thin sections because their formation mechanism changes irreversibly during the burial of host sediments.

\section{Palaeostress studies in the Alcapa unit}

Within the TR, examples of complex fault-slip analysis, combined with subsurface or surface mapping are from the Bakony and Keszthely Hills (CSICSEK 2015, CSICSEK \& FODOR 2016; HÉJA 2015, 2019). These works demonstrated the heterogeneous compressional directions during the Cretaceous orogeny, but also revealed multistage shortening and few Cenozoic stress fields (Figure 1, B). Data on Cretaceous deformation slightly modified the pioneer work of TARI (1994) and TARI \& HORVÁTH (2010) who described in detail the Cretaceous deformation of the TR.

In the Gerecse Hills, FODOR et al. (2018) summarised available structural data for the area and gave detailed structural evolution; separating spatially and temporally changing stress fields in the Cretaceous (mostly in accordance with SASVÁRI 2008b, 2009b); such variable Cretaceous deformation is unique for the TR. The data of SzIVES et al. (2018) presented only briefly these Cretaceous phases but clarified by biostratigraphy the temporal extent of the first and second ones. On the other hand, Cenozoic evolution of the Gerecse outlined by FODOR et al. (2018) is broadly similar to that of the Vértes Hills (FoDOR 2008) (Figure 1, B). Based on the combination of mapping and fault-slip data they changed the age classification of certain faults from Cenozoic to Mesozoic (compare FoDOR et al. 2018 and BADA et al. 1996).

In the Dorog Basin BERECZKY (2011) determined 7 stress fields, two of them were Cretaceous in age and fit to the evolution of the nearby Gerecse Hills (Figure 1, B). The two Palaeogene stress fields show similarities to those of the Gerecse and Buda Hills, while the mid-Miocene is interpreted as strike-slip deformation, which is at odds to results from the surroundings.

In the Visegrád Hills the combination of Danube river seismic data, geological and geophysical maps revealed important tensional, locally transtensional deformation 
(OLÁH et al. 2014); $\sigma_{3}$ was in roughly in NE-SW direction (Figure 1, C). Normal faults could be connected to E-W dextral faults, one having been exposed temporally below the Danube (BENCZE et al. 1991).

The stress fields of SIPOS-BENKŐ et al. (2014), derived from the entire $T R$, were basically similar to those found by earlier studies (MÁRTON \& FODOR 2003, FODOR 2008). The notable exceptions were the Late Miocene stress fields they assumed a change in minimal stress direction from $\mathrm{E}-\mathrm{W}$ to NW-SE being coeval with a counterclockwise rotation event (Figure 1, C). This model needs additional data.

In northern Hungary, several works described in detail the evolution of stress fields and map-scale fault patterns. These works were not independent from each other, and mutually used common time constraints or stress directions. PETRIK et al. $(2014,2016)$ refined the stress evolution in the southern Bükk foreland and southern Darnó Zone (Figure $1, D)$. Stress axes are close to the ones of FodOR (2010) but, with the help of new radiometric ages of volcanoclastic rocks (LUKÁcs et al. 2015, 2018), the age of rotations, and the boundaries of correlative phases have been shifted toward younger ages. PETRIK (2016) went even further in separating 11 phases from the Eocene to present. Although the number of phases, their separation can be discussed, this is the most detailed stress field evolution suggested in the Pannonian Basin. In this work, the time spans of rotations were slightly shifted again toward younger ages. More to the south, in the Polgár Basin PETRIK et al. (2019) found evidence for a change in the stress field, from strike-slip to extensional character, based on structures and magmatic features analysed on seismic 3D data sets.

Concerning the deformation bands, in recent works conducted in north-eastern Hungary BEKE (2016) and BEKE et al. (2019) were able to demonstrate that only 100-200 m of burial leads to change in mechanism, and 500 to $1000 \mathrm{~m}$ of burial corresponds to another change in mechanism. While the former burial depth could occur during only several ka to maximum 2-3 Ma, the study of DBs permits a temporal resolution previously unobtainable. In the latest work BEKE et al. (2019) suggested 10 phases from 27 Ma to present based on a combination of observations (Figure 1, C). The separation of D2 from D5 phase was possible by tilt test, the repetition of ESE-WNW tension, both characterising D6 and D9 phases, needed relative chronological criteria, and the separation of phases D4 and D5 is necessary if rotation event is incorporated in the story (Figure 1, D). With a new technique ALBERT et al. (2018) analysed in detail the complete fracture system of the Tar quarry and found the same extensional deformation like other studies in the region (BENKOVICS 1991, BEKE et al. 2019).

The last palaeostress analyses in north-eastern Hungary were concentrated on Mesozoic deformations, thus their contribution was more significant to Mesozoic than to Cenozoic stress field evolution. In the southern Bükk Mts., in the quarry of Bükkzsérc ORAVECZ (2016) recognised Jurassic normal faults and associated slump folds having formed by SE-NW extension (Figure 1, D). After correction of the block rotations, this deformation can be reconciled with the Jurassic palaeogeographic position of the Bükk in the Neotethyan framework (ORAVECZ et al. 2017). The established post-Jurassic stress fields show similarities to those observed by NÉMETH $(2006,2007)$ partly in the same quarry; these are the N-S compression, ENE-WSW (or EW) compression. In the south-western Bükk Mts. SCHERMAN (2018) and FIALOWSKI (2018) used the tilt test to verify pre-tilt WNW-ESE to NW-SE shortening. This direction should be close to the regional compression, which could characterise the nappe emplacement (SCHERMAN et al. 2018). ORAVECZ et al. (2018) concentrated to the Nekézseny fault at the boundary of the Bükk and Uppony Mts. The authors verified the NW-SE compression which resulted in folding and even overturning of the Senonian strata; the arguments favour latest Cretaceous timing of deformation. In fact, this is the fourth stress field of FODOR et al. (2005) which was poorly constrained at that time. The subsequent Cenozoic events follow the general stress field evolution of the northern Pannonian Basin.

In the Rudabánya Hills, post-early Badenian ESE-WNW extension was confirmed by several studies, partly based on deformed Pannonian strata located in very small grabens (DEÁK-KöVÉR 2012, HoRVÁTH et al. 2012). These studies also suggested the compressional-transpressional stress regime for the Early Miocene phase of the Darnó Zone.

Finally, in the latest work ORAVECZ (2019) demonstrated Triassic salt structures in the Aggtelek Hills which were reactivated by $\sim \mathrm{NW}-\mathrm{SE}$ compression during the Cretaceous orogeny and were affected by few poorly dated Cenozoic phases (Figure 1, D). This result changes the interpretation of folds, having been considered only as contractional features (GRILL 1989, CsONTOS \& HIPS 1997). Also the demonstration of salt structures and their reactivation seem to explain the long-time observed "youngon-older type" fault contacts previously interpreted simply as thrusts (HIPs 2001, FODOR et al. 2006).

\section{Palaeostress studies within or near the Periadriatic and Mid-Hungarian Fault Zones}

South from the rigid part of the Alcapa unit, the wide, strongly deformed Mid-Hungarian Shear Zone (MHZ) has no outcrop within Hungary. However, the Periadriatic Fault zone, equivalent to the northern branch of the MHZ is exposed in northern Slovenia. FODOR et al. (1998) verified the recurring dextral slip along and near the Slovenian Periadriatic Fault zone; the compressional or strike-slip regime was only interrupted with a short period of E-W transtension during the Karpatian (17.5-16 Ma) (Figure 1, $A$ ). The deformation comprised clockwise and counterclockwise block rotations, probably during two time slices. The post-Miocene dextral slip of the Šoštanj Fault (southern branch of the Periadriatic Fault zone) was verified by VRABEC (1999) and VRABEC et al. (1999); syn-tectonic fill of the Pliocene Velenje Basin provided a good time constraint.

Further to the east, along the transition of the Periadriatic and Balaton faults in Slovenia MÁrTON et al. (2002) de- 
monstrated the post-Miocene (neotectonic) compression and CCW rotation; these events are similar to ones observed west and east of this area (FodOR et al. 1998, ToMLJENOVIĆ et al. 2001). The neotectonic compression was preceded by NNE-SSW tension related to the Miocene opening of this part of the Pannonian Basin (Figure 1, A).

The southern-south-western part of the Pannonian Basin around the Medvednica and Ivanščica Mts. is one of the most complex area where the structural evolution shows connections to all the Periadriatic Fault, the Mid-Hungarian Shear Zone, the Dinarides and to the Tisza-Dacia unit. In this area TomLJENOvić \& CsONTOS (2001) demonstrated a complex Neogene structural evolution using stress field data and seismic reflection profiles (Figure 1, E). This evolution was marked by alteration of compressive and extensive phases and terminated by latest Miocene to recent folding (inversion of this part of the Pannonian Basin). In their later work TOMLJENOVIĆ et al. (2008) characterised the Oligocene-Early Miocene stress field and demonstrated a $130^{\circ}$ clockwise rotation, which distorted pre-Oligocene structures from their original Dinaridic orientation. Two postOligocene counterclockwise rotations complicate the stress field evolution.

The Hungarian part of the MHZ was analysed by seismic reflection profiles; in such an approach, the stress axes were only approximatively inferred from the map pattern of faults. In this line, SKORADY (2010) verified the dextral, Olgiocene to early Miocene (pre-Karpatian) kinematics of the northern fault branch of the MHZ, associated to thrusts and folds more to the north. She also observed the syn-rift extension and neotectonic compression.

More to the north-east, CsonTos et al. (2005) estimated Early to Mid-Miocene NW-SE compression and late Miocene to Quaternary(?) transtension along the middle part of the Mid-Hungarian Shear Zone, south of the Lake Balaton. This study completed earlier works of BALLA et al. (1987) and Csontos \& NAgYMarosy (1998) about the shear zone but added map representation of fault kinematics and estimated stress axes.

In a small area south from the Lake Balaton VÁRKONYI (2012) found 4 phases and he estimated the stress axes from the fault patterns. Pre-Karpatian dextral slip, Sarmatianearly Pannonian compression and reactivated neotectonic strike-slip faulting are similar to other studies. The direction of roughly N-S Karpatian-Badenian transtension seems to be a new feature but supported by the seismic data. The neotectonic strike-slip faulting was confirmed by VISNOVITZ et al. (2015) and extended below the Lake Balaton. Töró et al. (2012) extended the observation of pre-rift dextral strikeslip faulting, and the early Late Miocene strike-slip type deformation, but they did not provide map or stress axes.

Although RUSZKICZAY-RÜDIGER (2007) and RUSZKICZAYRÜDIGER et al. (2007) mostly studied the neotectonic, post-4 Ma deformation of the Tóalmás segment of the MHZ, they recognised pre-rift compression, the early and late syn-rift phases (18-14 and 14-11.6 Ma) and the early Late Miocene sinistral slip of the fault zone. The study of seismic sections demonstrated NNW-SSE compression within a larger area near the Tóalmás Fault (PALOTAI \& Csontos 2010, PALOTAI 2013). The fold-and-thrust belt started to form during the Kiscellian and lasted to the end of Early Miocene (Figure 1, A). Inversion of late Sarmatian to earliest Pannonian in age, and sinistral transtension of early Pannonian age were also demonstrated along the Tóalmás Fault.

In the north-eastern end of the MHZ, at the Alcapa-Tisza junction, below the north-easternmost corner of the Pannonian Basin, Ciulavu et al. (2002) demonstrated positive flower structures along the major boundary fault zones of the two units. They suggested post-Miocene deformation and NE-SW compression. Slightly to the east, in the Maramures area TISCHLER et al. (2007) extended the data base of GYÖRFI et al. (1999, see below). They confirmed the importance of NW-SE and NE-SW compression and transpression, already found by GYÖRFI et al. (1999), which were responsible for the Alcapa thrusting onto Dacia and sinistral displacement of the Bogdan Voda-Dragos Voda fault system, respectively (compare Figure 1, $A$ and $E$ ). Their precise timing was supported by fission track and sedimentological data.

\section{Palaeostress studies in the Tisza-Dacia unit}

South from the Mid-Hungarian Shear Zone, in the Tisza-Dacia unit the outcrops are not very extended in the Hungarian part. However, fault-slip and palaeostress studies were intensive in this unit, partly along the south-eastern margin of the Pannonian Basin and partly in the MecsekVillány area (Figure 1, E).

The first data in the Mecsek-Villány Mts. (BERGERAT \& CsOnTOS 1988) and the re-evaluation of field data (CsONTOS \& BERGERAT 1993) emphasised the importance of strike-slip faults, and suggested 3 strike-slip phases and the reoccurrence of one of them during the Pliocene. TARI (1993) also contributed to the fault kinematic analysis recognising leftlateral transtensional to transpressional deformation through Early to Late Miocene in the northern imbricate zone of the Mecsek.

GYÖRFI (1993) and GYÖRFI \& CsONTOS (1994) established NE-SW tension in the grabens of the Apuseni Mts., at the south-eastern margin of the Pannonian Basin. Later GYÖRFI et al. (1999) described one compressional and two strike-slip type deformation phases in the boundary zone of the TiszaDacia and Alcapa units, the second phase was attributed to the thrusting of Alcapa onto the Tisza-Dacia unit.

In the Mecsek and Villány Mts. BenKovics (1997) elaborated in detail the structural evolution. He found three Permo-Mesozoic phases, including late Cretaceous NWSE compression (BENKOviCs et al. 1997). For the Cenozoic, he documented six phases, partly transtensional with NW$\mathrm{SE} \sigma_{3}$, partly strike-slip (N-S $\sigma_{1}$, during 16-13 Ma) and established the latest Miocene to Quaternary shortening and inversion of both the Mecsek and Villány Mts. from ca. 7.5 Ma. He also incorporated the clockwise block rotation at the end of Early Miocene and also a differential rotation between the Northern Imbricate Zone and other units. 
All these studies were incorporated in the third palaeostress summary, which already taken account the different rotation pattern of the Tisza-Dacia with respect to the Alcapa unit (Figure 1, A).

After this synthesis Csontos et al. (2002a, b) improved the understanding of the evolution of the stress field, by describing varying transpressional, strike-slip phases, interrupted by clockwise rotation, late Miocene tension to transtension, and latest Miocene to recent (neotectonic) transpression in the entire Mecsek-Villány area (Figure 1, E).

In the Villány Hills PETRIK (2009) determined 6 stress fields. While data were registered on Mesozoic rocks, timing seems to be questionable and the stress axes are different from the results of others. Along the southern margin of the Mecsek Mts. SEBE \& DeZsó (2008) and SEBE \& KONRÁD (2009) documented stress data from few sites, indicating thrusting during latest Sarmatian and the late(?) Pannonian. Konrád \& SEBE (2010) extended the stress database and demonstrated dozens of outcrops with smallscale structures. Using this dataset they characterised the young deformations along the main fault zones of the Mecsek Mts.

Extensive data set has been accumulated during the research of the potential nuclear waste depository site south of the Mecsek Mts., in the Mórágy Hills. Despite the extremely large dataset and detailed interpretation (see summary of BALLA et al. 2009), conclusions regarding the palaeostress fields are less abundant. As part of this extensive study MAROS et al. (2004) documented two Palaeozoic, three Mesozoic and five Cenozoic stress fields. After late Cretaceous NW-SE tension, the Early and Middle Miocene were characterised by transpressional stress fields, while their connected faults were passively rotated in clockwise direction.

In the Mecsek Mts. few additional stress data were published after 2010. KovÁcs et al. (2018) determined Pannonian syn-sedimentary strike-slip deformation and postsedimentary transpression (Figure 1, E). In the Mórágy area, combination of structural and sedimentological data suggest that syn-sedimentary faulting by $\sim \mathrm{N}-\mathrm{S}$ compression and perpendicular tension controlled the sedimentation between $8-6.5 \mathrm{Ma}$, and this phase was followed by folding in the same stress field (BUDAI et al. 2019).

\section{Discussion}

\section{Some concluding remarks on the stress field evolution}

This summary demonstrates that our idea on the stress field evolution comprises more and more deformation phases. I think that this is real, the Cenozoic stress field evolution in NE Hungary was at least as complex as the models of FODOR (2010), PETRIK et al. (2014), PETRIK (2016) and BEKE et al. (2019) (see on Figure 1), although new data may modify the number of phases and their timing. The presently suggested structural evolution means a temporally frequently changing fault pattern, particularly in the Miocene, during the formation (rifting) of the Pannonian Basin. It is also clear that spatial differences in the maximal horizontal stress axes were fundamental during certain phases within the Pannonian Basin; such regionally varying stress fields imply coherently varying fault patterns and eventually fault kinematics, too. A simple, idealistic fault pattern with identical orientations and kinematics across the entire basin was certainly not the case during most of the rifting events. This complexity in the stress field and fault pattern evolution was suggested earlier (e.g. FoDOR et al. 1999) and has supported by more recent studies.

\section{Problems and possible solutions}

At the end of this overview I mention some of the problems of palaeostress determination and fault-slip analysis in general. These concerns raised during the research in the Pannonian Basin, but the international publications contain even wider spectrum of problems (e.g. SPERNER \& ZWEIGEL 2010).

A) During fault-slip analysis most of us do not like to "loose" even a single fracture. Thus we may "over-interpret" the few fractures remaining after phase separation and they seems to form a "new" stress field. It is equally true for striated faults, the last 4-5 faults which do not fit to any formerly separated phases may fit to a new stress field, albeit with large misfit values. Sophisticated phase separation can also lead to "apparent phases" when only the mathematical misfit criteria are taken into account, and the geometrical connection of fractures is not considered. Joints are difficult to interpret and needs care, because their origin is not necessarily due to crustal stress (but to cooling, slope failure, dewatering etc.). Orthogonal sets of joints could also form at the same time, and not subsequently; at least such solution was suggested for cases when $\sigma_{3}$ and $\sigma_{2}$ are very close to each other and permutation of axes was possible (ANGELIER \& Bergerat 1983, TiBAldi 1992, ACOCELla \& Funiciello 2006). All these pitfalls may lead to overestimate the number of stress fields (phases) in a given area.

B) During the last decade we demonstrated that very similar or even identical stress axes and related fault pattern did occur in two or more temporally separated phases during the Mesozoic-Cenozoic structural evolution. When tilt test can be applied (dip is larger than ca. $10-15^{\circ}$ ) the separation of the two temporally separated, but similarly oriented phases is possible. Figure 2 shows 4 examples of such cases. NW-SE compression characterised both the Bakony and Vértes Hills during the Cretaceous (early Albian) contraction (D3a phase of FODOR 2008, 2010), while a very similar compression reoccurred during the late Oligocene to early Miocene (D7 and D8 phases of the same works). NE-SW tensional stress field was characteristic during several phases, namely during Triassic (HÉJA et al. 2018) and Jurassic extension, late Cretaceous (Senonian) extension (KISS 2009), and during the main syn-rift phase of the Pannonian Basin (Fodor et al. 1999). Figure 2 shows that similar stress fields occurred during the 
late Oligocene to earliest Miocene in the Bükk foreland (PETRIK et al. 2014, 2016; PETRIK 2016) prior to or during the first tilting event which pre-dated the main syn-rift phase. This means that a NW-SE striking fault in Triassic rock could be active in 4 or 5 phases with normal kinematics providing that it was not tilted much during any of the deformation phases. $\mathrm{N}-\mathrm{S}$ compression could also be active during several phases, starting from the Cretaceous (BADA et al. 1996), during the syn-rift phase and also during the neotectonic deformation. In the Miocene (Karpatian) sediments of the Pohorje Mts., tilt test demonstrated the reoccurrence of this stress field during and after the Miocene (Figure 2) (FODOR et al. 2008b).
C) We would need independent time constraints to classify the fracture sets of each studied outcrops; a requirement generally not fulfilled. The "general solution" is the classification of separately determined stress states with similarly oriented axes into a common phase. Such "directional classification" will inevitably lead to a stress field with parallel principal axes in each observations points ("homogenous stress field" in a slightly unprecise jargon), and a stress determination, whose axial direction is different from the dominant one will be separated into a different phase. In this simple way, any directional variability of the stress field across a basin can hardly be demonstrated.

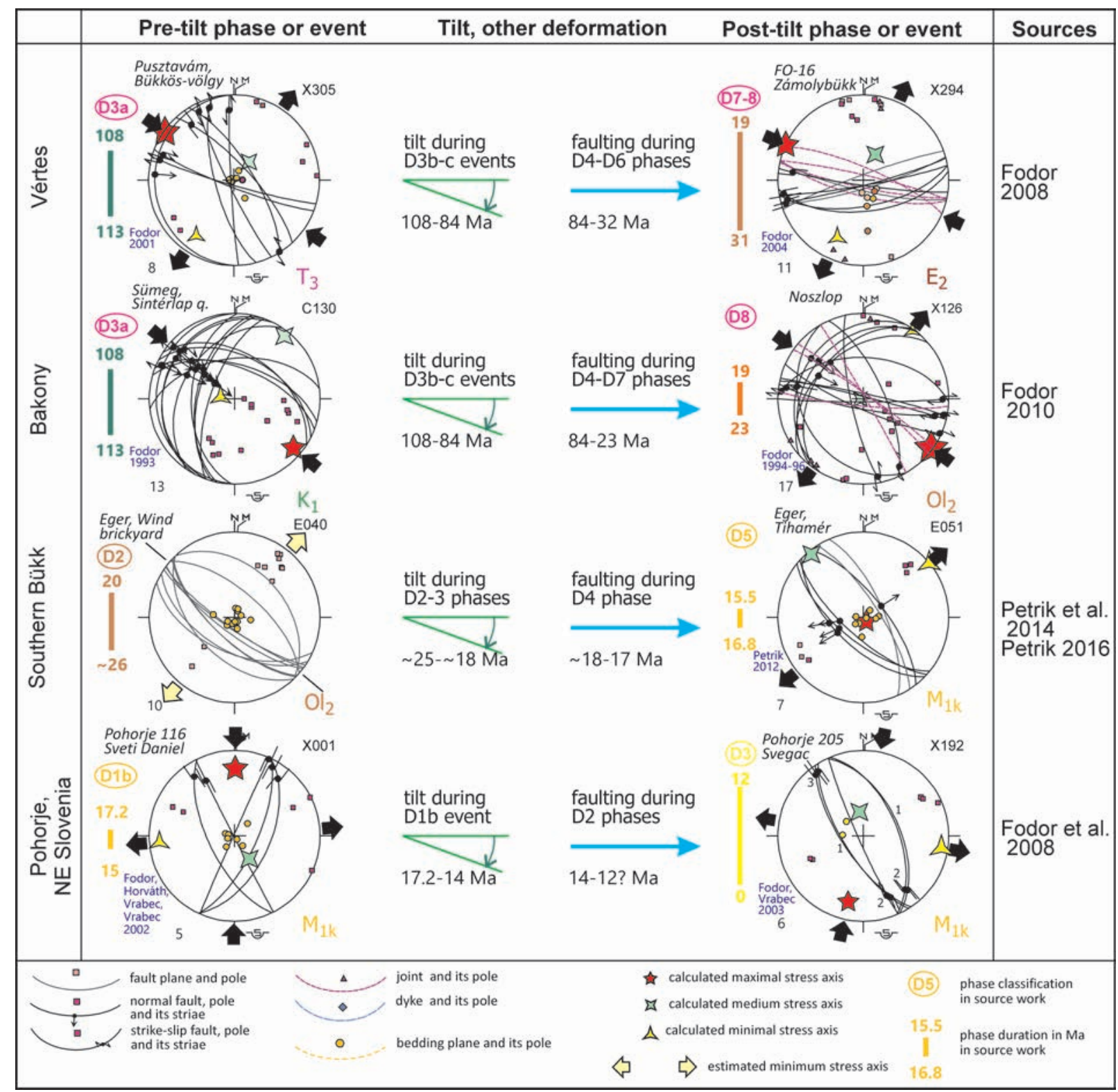

Figure 2. Demonstration of repetition of the same stress regime during the tectonic evolution. Tilt test clearly shows the reoccurrence of the principal stress axes of a pre-tilt phase during a younger post-tilt phase. Note time spans of pre-and post-tilt phases and the tilt itself; they vary in each cases C, X, E in upper right hand corner indicate compressional, strike-slip and tensional stress regime

2. ábra. A szerkezetfejlódés során ismétlödö feszültségmezók kimutatása. A billentésteszt egyértelmüen kimutatja a kibillenés elötti idösebb feszültségtengelyeknek egy fiatalabb, kibillenés utáni fázisban való újbóli megjelenését. A jobb felsö sarokban a C, X, Ejelek a kompressziós, eltolódásos és tenziós feszülltségrezsimet jelzik 
To illustrate the problem of "homogenous" versus "heterogeneous" stress field (with parallel or variable principal stress directions, respectively), Figure 3 shows a case study from the southern TR. In his early work, HÉJA (2015) determined three compressional stress states, with maximal stress axes at $\sim$ E-W, NW-SE and NE-SW, and classified them into two or three different deformation phases from Cretaceous to early Cenozoic (D3, D4, and D3 or D6, respectively). In his revised version (HÉJA 2019), all different stress states belong to the same Cretaceous deformation phase which had a strongly variable maximal stress direction. The variability of the principal stress directions is due to inherited Triassic structures which buttressed the deformation and resulted in contractional-compressional structures, expressed both by folds and faults, whose orientation changed from place to place. This interpretation seems to be more realistic because takes into account the effect of older structures inherited for the Cretaceous shortening phase.

The problem of stress axes classification cannot overcome easily, only if we can improve the time constraints by different methods. Most commonly, one can search for relative chronological data of different fracture sets (and derived stress states), carry out tilt test, which establish relative chronology with respect to a temporally constrained tilting event, execute mineral vein investigation, and check the relationship of fractures to deformation bands and/or to burial and diagenetic history. Absolute dating of calcite fibres or dominoes related to fault slip would be the ultimate solution but this method is still not easily accessible although several works validated the method (e.g. NuRIEL et al. 2012, ROBERTS \& WALKER 2016).

D) Figure 1, $A-D$ shows a frequent and important changes in stress axes; however, the fault pattern of outcrop-scale does not seem to be reflected in the pattern of major faults figured on available basin-scale maps. The solution for this problem is equivocal; (1) we over-interpreted the outcrop-scale fracture pattern, and some of the suggested phases have very localised extension and are just due to local effects (stress perturbation, more complex relationship between stress and fractures including nonindependent slip on connected faults, etc.), (2) reactivation by oblique-slip or strike-slip of pre-existing major faults; the number of map-scale faults will not increase, but on outcrop-scale small new faults favourably oriented to new stress axes could form.

E) For long time, the problem of rotation and changes in stress field seemed to be solved (MÁRTON \& FODOR 1995, 2003) while suggesting coeval rotations and changes of stress axes mostly due to rotations. However, as more data have been collected by both palaeomagnetic and faultslip techniques, new problems emerged. These are the post-Middle Miocene rotations within the Transdanubian Range, indicated by palaeomagnetic data (MÁRTON et al. 2006). Such a rotation could be reflected in stress data, but for Late Miocene, they have poor temporal constraints (SIPOS-BENKó et al. 2014) and it is not clear if differences in stress axes are due to local variations or to the rotation. In addition, map-scale structures do not reflect any Late Miocene deformation which would be suitable to accommodate larger than $20^{\circ}$ rotations; thus these rotations should be local but even such map-scale structures are still missing. The other problem is that new palaeomagnetic data and precise absolute ages of the Bükkalja Miocene volcanic levels clearly show mismatch; rotation seems to be present even in the Harsány horizon (MÁRTON et al. 2007) which was dated as the youngest one on surface (14.358 $\pm 0.015 \mathrm{Ma}$, LuKÁCS et al. 2018), while other sites showing no rotation seem to be older (14.88 $\pm 0.014 \mathrm{Ma}$, Demjén ignimbrite). Complex and comparative studies, surface and subsurface mapping, and deeper understanding of the processes (magnetisation, deformation, crystallisation versus eruption) will be necessary in the future.

F) One of the ultimate goals for outcrop-scale fault-slip analyses was the understanding of fault kinematics of large structures, like the Darnó, Mecsekalja, Balaton or MidHungarian Shear Zones. Because most of these fault zones are covered by young sediments, kinematic determination would only be possible if we could project surface kinematic or stress data to the faults, which needs the supposition of a homogenous stress field, and a mechanically uniform Pannonian Basin. We know that this is not the case, and the structural evolution of the basin has been governed by the inheritance of major discontinuities, like the mentioned fault zones. Near these structures specific stress conditions should be present, like, for example, the closely perpendicular compression along the strike-slip San Andreas Fault (ZOBACK et al. 1987). The kinematics of these major faults are governed by large-scale plate tectonic processes, and the fault zones could play the role of transfer faults accommodating differential extension or contraction; such scenario was postulated by TARI et al. (1992), Csontos \& Nagymarosy (1998) for the Miocene. The solution is easy to be outlined but more difficult to provide; we need detailed kinematic analyses of the major fault zones by all available data, mostly by modern 3D seismic data (like the works of PALOTAI \& CsONTOS 2010, PETRIK et al. 2019), analogue and computer modelling of the role of fault inheritance on kinematics, stress, and rotation (like the work of BALÁZS et al. 2017).

\section{Future perspectives}

We can put the question if the era of fault-slip and palaeostress analysis has been terminated or not? Looking to the poor structural geological imaging of our country, the answer is definitely no. Every new observation contributed to imaging the fault network, and will continue to do so. Such studies will describe fault kinematics, stress fields and their evolution; still a large part of the country (both in outcropping and covered areas) has not been surveyed yet in detail. However, isolated fault-slip analysis will not be enough. Integration of surface structural data with seismic profiles, particularly with modern 3D data sets, boreholes 


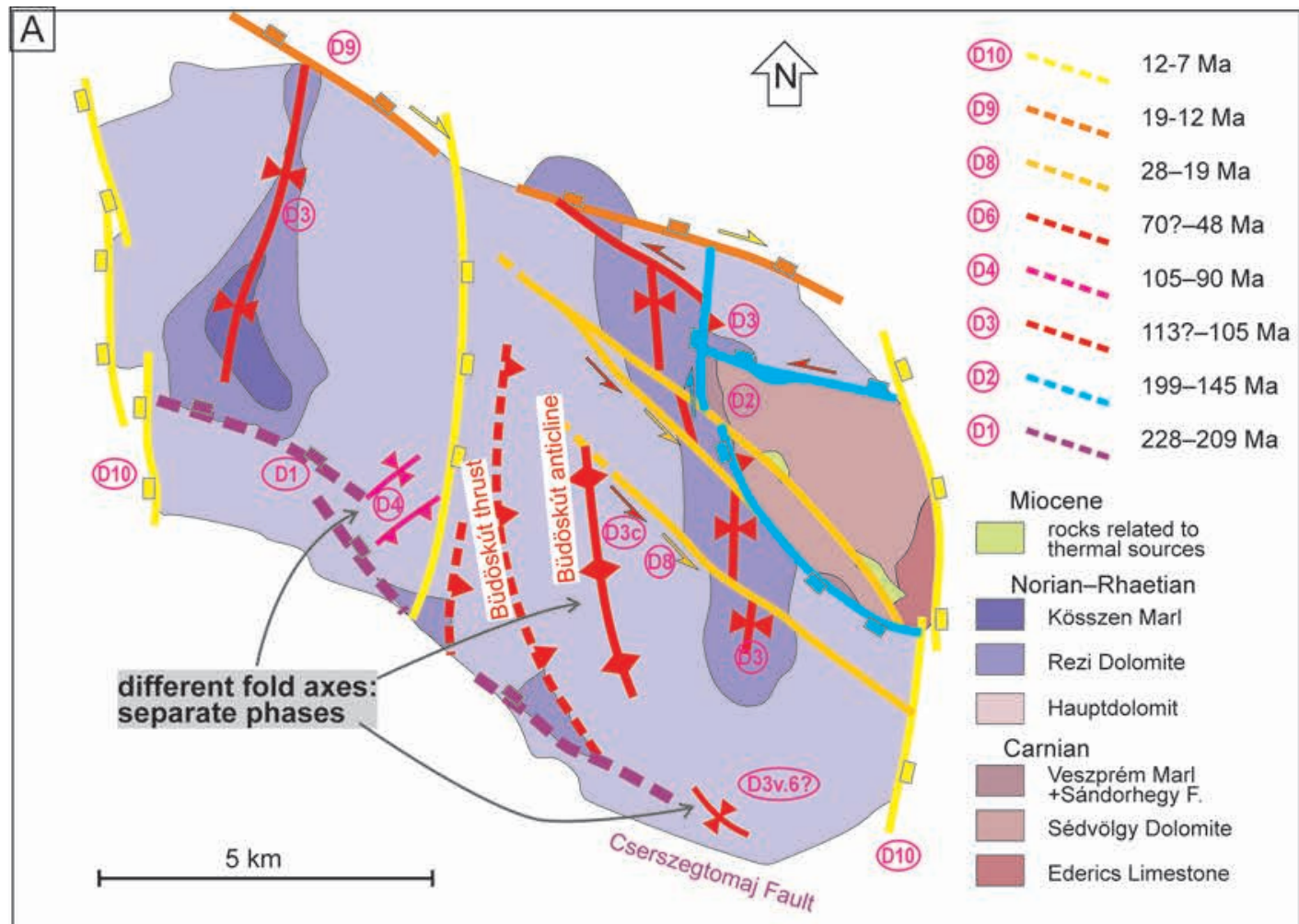

$\mathrm{B}$

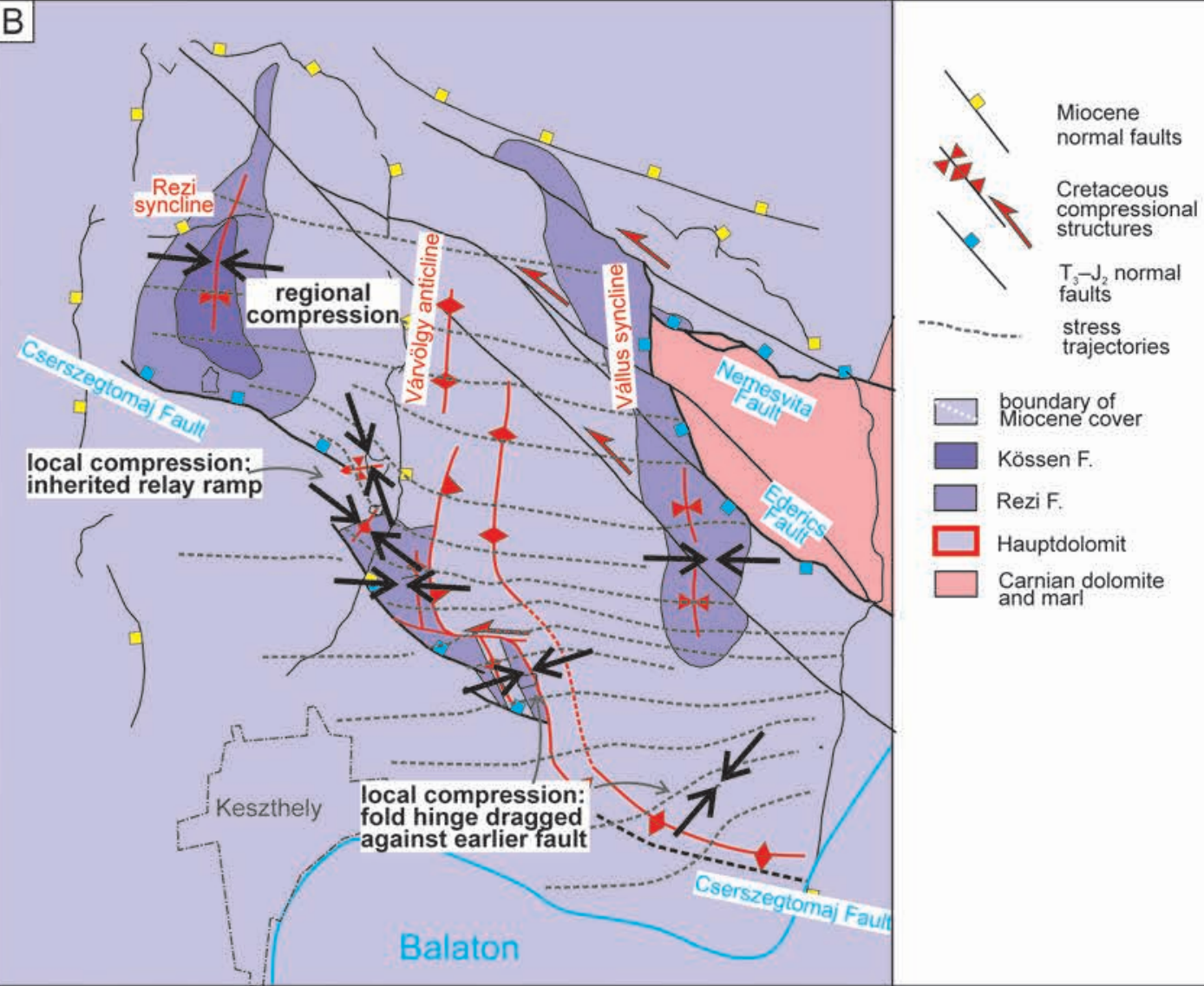

Figure 3. Comparison of classification of individual stress determinations. A) Separation into directionally homogenous stress fields (HÉsA 2015, modified). B) All contractional deformation are grouped within one phase with highly heterogeneous stress fields (after HÉJA 2019, modified). Note curved stress trajectories near buttressing inherited normal faults

3. ábra. Az egyedi feszültség-meghatározások csoportositásainak összehasonlitása. A) Az irány szerint homogén feszültségmezöbe való sorolás HÉJA (2015) munkája alapján, módositva. B) Minden rövidüléses-kompressziós deformáció egy fázisba való sorolása igen heterogén feszültségmezöhöz vezet (HÉJA 2019, módosítva). A feszültség-trajektóriák az átöröklött normálvetök hatása miatt ivelödnek 
and diverse geophysical data should be the basis of future analyses. All this should lead to map or 3D visualisation of the brittle structural framework. In this line, new techniques, like the usage of Remotely Piloted Aircraft combined with 3D photogrammetric model, will help understanding the 3D fracture geometry (TÖRÖK et al. 2018, ALBERT et al. 2018). If combined with kinematic analysis these methods will help palaeostress estimations, too.

The analysis of deformation bands will serve further detailed understanding of fracture evolution because we will be able to date such fractures with good precision. In addition, rheological evolution of the deforming media will be followed, and, as probably most importantly, fluid flow evolution along these fractures will be described. The presently ongoing structural diagenetic research will connect deformation, burial, diagenesis, and fluid flow (SzŐCs et al. 2018). This topic leads already to a major challenge, to understanding the role of fractures in fluid flow, basin-wide and locally. From the "fluid side" several results are embedded in publications (HAVRIL et al. 2016, 2018) and in divers applied researches like those conducted at geothermal fields and reconstruction of fracture network; its connection to fluid flow and mineralisation is under way in several parts of the Pannonian Basin (DABI et al. 2013, BAUER \& M. TóTH 2017, М. То́тн 2018). Although this is not strictly the topic of fault-slip analysis, but potentially, this will be the field where hydrogeology, hydrocarbon geology and brittle structural geology would (should) meet. Studies in this respect have been published (e.g., SZABó et al. 2016, GARAGULY et al. 2018) and future efforts will follow.

\section{Acknowledgement}

First of all I express, surely in the name of the Hungarian structural geologist community, our thanks to Françoise BERGERAT (Paris), who introduced us in the palaeostress studies, both in the field and in laboratories. Without her fundamental contribution and patient guidance, our work would not have been possible or would have been retarded for years. Several colleagues, MSc and PhD students contributed to the field measurements and laboratory analyses. As I mentioned in the Introduction, Frank Horváth was really the person who catalysed and supported the earlier studies.

The research direction for palaeostress determination and fault-slip analyses was supported by a large number of scientific research grants. The present paper is a contribution to research supported by the NKFIH OTKA grant 113013 led by L. FoDOR. Comments of the four reviewers largely contributed to the improvement of the text, and their remarks were mutually complementary. László CsONTOS suggested rearrangement of the text and Figure 1, which was mostly accepted in the new version. Norbert NÉMETH criticised and corrected some of the concepts and some structural terms and he drew my attention to several publications. Attila PETRIK suggested better formulation of sentences and thoroughly checked the reference list and the missing items. An anonymous reviewer observed mistakes which avoided the eyes of the others. I profoundly acknowledge all these helps.

\section{References — Irodalom}

ACOCELla, V. \& Funiciello, R. 2006: Transverse systems along the extensional Tyrrhenian margin of central Italy and their influence on volcanism. - Tectonics 25, TC2003, 24 p. https://doi.org/10.1029/2005TC001845

ÁdÁM A., Fodor L., SZAFIÁN P. \& MURÁTI J. 2001: Szerkezeti vonalak, tektonikai blokkok határainak pontosítása geofizikai és geológiai módszerekkel. — In: ÁdÁM A. \& MEsKó A. (eds): A földtudományok és a földtani folyamatok kockázati tényezói. Akadémiai Kiadó, 45-71.

Albert, G. 2000: Az Északi-Bakony gyưrődései. — MSc thesis, Eötvös University, Dept. General and Historical Geology, 89 p.

Albert, G., Mészáros, J. \& Szentpétery, K. 2018: Structural analysis of a Miocene ignimbrite quarry (Tar, Hungary) based on 3D photogrammetric model. - Poster presented at EGU meeting, 2018.

AleXANDrovski, P. 1985: Graphical determination of principal stress directions for slickenside lineation populations: an attempt to modify Arthaud's method. — Journal of Structural Geology 7, 73-82. https://doi.org/10.1016/0191-8141(85)90116-6

ALMÁsI I. 1993: A Gánt környéki bauxitterület szerkezetföldtani vizsgálata. — MSc thesis, Eötvös University, Dept. Applied and Environmental Geology, 94 p.

ANDERSON, E. M. 1905: The dynamics of faulting. — Transactions of the Edinburgh Geological Society 8, 387-402.

Anderson, E. M. 1951: The dynamics of faulting and dyke formation with application to Britain. - Oliver \& Boyd, Edinburgh, $2^{\text {nd }}$ edition, $206 \mathrm{p}$.

ANGELIER, J. 1979a: Determination of the mean principal directions of stresses for a given fault population. — Tectonophysics 56, 17-26. https://doi.org/10.1016/0040-1951(79)90081-7

ANGELIER, J. 1979b: Néotectonique de l'Arc Egéen. — Société géologique du Nord, Publ. 3, 418 p.

ANGELIER, J. 1984: Tectonic analysis of fault slip data sets. — Journal of Geophysical Research 89, B7, 5835-5848. https://doi.org/ 10.1029/jb089ib07p05835

ANGELIER, J. 1990: Inversion of field data in fault tectonics to obtain the regional stress, III. A new rapid direct inversion method by analytical means. — Geophysical Journal International 103, 363-373. https://doi.org/10.1111/j.1365-246x.1990.tb01777.x

ANGELIER, J. \& BERGERAT, F. 1983: Systèmes de contrainte et extension intracontinentale. — Bulletin Centres Recherches ExplorationProduction Elf-Aquitaine 7/1, 137-147. 
ANGelier, J. \& MANoussis, S. 1980: Classification automatique et distinction des phases superposée en tectonique de failles. —Comptes Rendus de l'Académie des Sciences 290, série D, 651-654.

ANGELIER, J. \& MECHLER, P. 1977: Sur une méthode graphique de recherche des contraintes principales également utilisable en tectonique et en séismologie: la méthode des dièdres droits. — Bulletin de la Société Géologique de France, sér. 7, 19/6, 1309-1318. https://doi.org/10.2113/gssgfbull.s7-xix.6.1309

ANGELIER, J., BARRIER, E. \& CHU, H.T. 1986: Plate collision and paleostress trajectories in a fold-thrust belt: the foothills of Taiwan. Tectonophysics 125, 161-178. https://doi.org/10.1016/0040-1951(86)90012-0

APRó M., SCHUberT F. \& VARGA A. 2014: A kompakciós és deformációs szalagok jelentősége homokkövekben a pannóniai Szolnoki Homokkő Formáció példáján. — In: PÁl-Molnár E. \& HaRAngI Sz. (szerk.): Közettani folyamatok a földköpenytól a felszínig: 5. Kőzettani és geokémiai vándorgyúlés Budapest, Magyarország: MTA-ELTE Vulkanológiai Kutatócsoport, SZTE ÁGKT Vulcano Kutatócsoport, p. 8

BADA, G. 1994: Evolution of the paleostress field in the Gerecse Hills and their southern and southeastern vicinity. — MSc thesis, Eötvös University, Dept. Applied and Environmental Geology, 147 p. (in Hungarian).

BADA, G. 1999: Cenozoic stress field evolution in the Pannonian basin and surrounding orogens: inferences from kinematic indicators and finite element modelling. - Ph.D. Thesis, Vrije University Amsterdam, 204 p.

BAdA, G., Fodor, L., SzÉKELY, B. \& TimÁr, G. 1996: Tertiary brittle faulting and stress field evolution in the Gerecse Mts. N. Hungary. — Tectonophysics 255, 269-290. https://doi.org/10.1016/0040-1951(95)00141-7

BALÁSHÁzy, L. 1977: Részletes tektonikai vizsgálatok az Észak-Vértes és Déli-Gerecse területén és a szerkezeti elemek vízföldtani kapcsolata. - PhD. thesis, Eötvös University, Dept. Applied and Environmental Geology. (in Hungarian)

Balázs, A., Burov, E., Matenco, L., Vogt, K., Francois, T. \& Cloetingh, S. 2017: Symmetry during the syn- and post-rift evolution of extensional back-arc basins: the role of inherited orogenic structures. — Earth and Planetary Science Letters 462, 86-98. https://doi.org/10.1016/j.eps1.2017.01.015

BALKAY B. 1960: Mikrotektonikai megfigyelések a Bükk-hegység északi részén. — Földtani Közlöny 90/1, 120-124.

BALLA, Z. 1984: The Carpathian loop and the Pannonian Basin: a kinematic analysis. — Geophysical Transactions 30/4, 313-353.

BALLA, Z. 1988a: Late Eocene tectonic pattern of the Carpatho-Pannonian region and its bearing on the Mesozoic reconstructions of Tethys. - Földtani Közlöny 118, 11-26.

BALLA, Z. 1988b: On the Origin of the structural pattern of Hungary. — Acta Geologica Hungarica 31/1-2, 53-63.

Balla, Z. \& DudKo, A. 1989: Large-scale Tertiary strike-slip displacements recorded in the structure of the Transdanubian Range. Geophysical Transactions 35, 3-64.

Balla, Z. \& DudKo, A. 1990: Folded Oligocene beds in Budapest. - Acta Geologica Hungarica 33, 31-42.

BALla, Z. \& DudKo, A. 1996: Törések pannóniai képződményekben. — Földtani Közlöny 126, 209-262.

Balla, Z., Dudko, A. \& Redler-TÁtrai, M. 1987: Young tectonics of Mid-Transdanubia based on geological and geophysical data. Annual Report of the Eötvös Loránd Geophysical Institute, 1986, 74-94. (in Hungarian)

Balla, Z., Császár, G., Gulácsi, Z., Gyalog, L., Kaiser, M., Király, E., Koloszár, L., Koroknai, B., Magyari, Á., Maros, Gy., MARsi, I., MolnÁr, P., Rotárné SzAlKai, Á. \& Tóth, Gy. 2009: Geology of the north-eastern part of the Mórágy Block. —Regional Map-series of Hungary, Explanatory Notes to the geological map-series of the north-eastern part of the Mórágy Block (1:10 000). ISBN 978-963-671-267-9

BAUER, M. \& M. TóTH, T. 2017: Characterization and DFN modelling of the fracture network in a Mesozoic karst reservoir: Gomba oilfield, Paleogene Basin, Central Hungary. — Journal of Petroleum Geology 40/3, 319-334. https://doi.org/10.1111/jpg.12678

BEKE B. 2010: Eocén korú töréses deformációk vizsgálata a Gerecsében. — MSc thesis, Eötvös University, Dept. Regional Geology, 115 p.

BEKE B. K. 2016: Role of deformation bands in structural evolution of Cenozoic porous sediments in NE Hungary. — PhD thesis, MTAELTE Geological, Geophysical and Space Science Research Group, 148 p. (in Hungarian with English abstract)

BEKE B. \& FodOR L. 2014: Deformációs szalagok porózus kőzetekben. — Földtani Közlöny 144/3, 255-274.

BeKe B., Fodor, L., Millar, L. \& PetriK, A. 2019: Deformation band formation as a function of progressive burial: Depth calibration and mechanism change in the Pannonian Basin (Hungary). — Marine and Petroleum Geology 105, 1-16. https://doi.org/10.1016/ j.marpetgeo.2019.04.006

Bencze, G., Császár, G., Darida-Tichy, M., Dudko, A., Gálos, M., Gangl, G., Kertész, P., Korpás, L. \& Zier, C. 1991: Geologische und ingenieurgeologische Beschreibung der Donaustufe Nagymaros. — In: LoBItZER, H. \& CsásZÁr, G. (editors), Jubiläumsschrift 20 Jahre geologische Zusammenarbeit Österreich-Ungarn 1, 385-400.

BENKOVICs L. 1991: A Zagyva-árokban végzett mikrotektonikai vizsgálatok és szeizmikus szelvényekkel való kapcsolata. — MSc Thesis, Eötvös University, Dept. General and Historical Geology, 95 p.

Benkovics, L. 1997: Étude structurale et géodinamique des Monts Buda, Mecsek et Villány (Hongrie). — PhD. Thesis, Université des Sciences et Technologies de Lille, France, 230 p. (No: 2080)

Benkovics, L., Mansy, J-L., Csontos, L. \& Bergerat, F. 1997: Folding in the roadcut of Abaliget (Mecsek Mts.). — Acta Geologica Hungarica 40/4, 425-440.

Benkovics, L., Obert, D., Bergerat, F., Mansy, J-L. \& Dubois, M. 1999: Brittle tectonics and major dextral strike-slip zone in the Buda karst (Budapest, Hungary). — Geodinamica Acta 12, 3-4, 201-211. https://doi.org/10.1080/09853111.1999.11105343

BENKó Zs., MoLNÁR F. \& LESPINASSE, M. 2008: Fluidzárványsíkok és repedésrendszerek vizsgálatának alkalmazása granitoid kőzetek repedezettségének fejlődéstörténeti rekonstrukciójában I.: Módszertani alapvetés és alkalmazás a Velencei-hegység fluidummobilizációs folyamataira. - Földtani Közlöny 138/3, 229-246.

Benkó, Zs., Molnár, F., Lespinasse, M., Billström, K., Pécskay, Z. \& Németh, T. 2014a: Triassic fluid mobilization and epigenetic lead-zinc sulphide mineralization in the Transdanubian Shear Zone (Pannonian Basin, Hungary). — Geologica Carpathica 65/3, 177-194. https://doi.org/10.2478/geoca-2014-0012 
Benkó, Zs., Molnár, F., Lespinasse, M. \& VÁcZI, T. 2014b: Evidence for exhumation of a granite intrusion in a regional extensional stress regime based on coupled microstructural and fluid inclusion plane studies e An example from the Velence Mts., Hungary. Journal of Structural Geology 65, 44-58. https://doi.org/10.1016/j.jsg.2014.04.001

BENKô K. 2000: Csővár környékének szerkezetföldtana. — Szakdolgozat, ELTE Alkalmazott és Környezetföldtani Tanszék.

BENKô K. 2005: A Móri-árok DK-i részének harmadkori szerkezetföldtani és paleomágneses vizsgálata. — Abstract kötet, XXXVI. Ifjú Szakemberek Ankétja, MGE-MFT kiadvány, Budapest, 27-28.

BENKő, K. \& FoDOR, L. 2002: Structural geology near Csôvár, Hungary. — Földtani Közlöny 132, 223-246. (in Hungarian with English abstract)

BERECZKY L. 2011 : Terepi szerkezetföldtani vizsgálatok a Dorogi-medence területéről. — MSc thesis, Eötvös University, Dept. General and Applied Geology, 93 p.

Bergerat, F. 1988 : Evolution des mécanismes d'extension dans le bassin pannonien. — Geodinamica Acta 2/2, 89-98. https://doi.org/ 10.1080/09853111.1988.11105159

Bergerat, F. 1989: From pull-apart to the rifting process: the formation of the Pannonian Basin. — Tectonophysics 157, $271-280$. https://doi.org/10.1016/0040-1951(89)90144-3

Bergerat, F. \& Csontos, L. 1987: Présence de microfailles hydroplastiques de compaction dans les lignites miocénes et pliocénes des massifs de Mátra et du Bükk (Hongrie): Interprétation dans le contexte extensif du Bassin Pannonien. — Comptes Rendus de l'Académie des Sciences Paris 305, 791-796.

Bergerat, F. \& Csontos, L. 1988: Brittle tectonics and paleostress field in the Mecsek and Villány Mts. (Hungary): Correlation with the opening mechanism of the Pannonian Basin. - Acta Geologica Hungarica 31, 81-100.

Bergerat, F., Geyssant, J. \& KÁzmér, M. 1983a: Une tectonique synsédimentaire originale du Miocène moyen des environs de Budapest, marqueur de l'extension du Bassin Pannonien. — Comptes Rendus de l'Académie des Sciences, Paris 296, 1275-1278.

Bergerat, F., Geyssant, J. \& LepVrier, C. 1983b: From pull-apart to the rifting process: the formation of the Pannonian Basin. Comptes Rendus de l'Académie des Sciences, Paris 296, ser. II, 1555-1558.

Bergerat, F., Geyssant, J. \& Lepvrier, C. 1984a: Etude de la fracturation dans le Bassin Pannonien: Méchanismes et étapes de sa création. - Annales de la Société Géologique du Nord 103, 265-272.

Bergerat, F., Geyssant, J. \& LepVrier, C. 1984b: Neotectonic outline of the Intra-Carpathian basins in Hungary. — Acta Geologica Hungarica 27, 237-251.

BíRó I. 2003: A Vértessomlói-törésvonal szerkezetföldtani vizsgálata a vértesi Mária-szurdok környékén. — MSc thesis, Eötvös University, Dept. Regional Geology, 73 p.

Bodor B. 2011: A Hernád-árok szerkezetföldtani vizsgálata. — MSc thesis, Eötvös University, Dept. Regional Geology, 99 p.

BOKOR Gy. 1939: A Budai-hegység nyugati peremének földtani viszonyai. — Földtani Közlöny 69, 219-259.

Bотт, M. H. P. 1959: The mechanism of oblique slip faulting. — Geological Magazine 96, 109-117. https://doi.org/10.1017/s0016756800059987

BREZSNYÁNSZKY, K. \& HAAS, J. 1990: Tectonic map of Hungary, 1: 500 000. — Hungarian Geological Institute, Budapest.

BREZSNYÁNSZKI, K. \& SíKHEGYI, F. 1987: Neotectonic interpretation of Hungarian lineaments in the light of satelite imagery. — Journal of Geodynamics 8, 193-203. https://doi.org/10.1016/0264-3707(87)90037-8

Budai, S., Sebe, K., Nagy, G., Magyar, I., Sztanó, O. 2019: Interplay of sediment supply and lake-level changes on the margin of an intrabasinal basement high in the Late Miocene Lake Pannon (Mecsek Mts., Hungary). — International Journal of Earth Sciences 108/6, 2001-2019. https://doi.org/10.1007/s00531-019-01745-3

Budai T., Császár G., Csillag G., Dudko A., Koloszár L. \& Majoros Gy. 1999a: A Balaton-felvidék földtana. Magyarázó a Balatonfelvidék földtani térképéhez, 1:50 000. — A Magyar Állami Földtani Intézet Alkalmi Kiadványa 197, 257 p.

Budai, T., Csillag, G., DudKo, A. \& Koloszár, L. 1999b: Geological map of the Balaton Highland, 1:50 000. — Geological Institute of Hungary, Budapest.

Budai, T., Fodor, L., Csillag, G. \& Piros, O. 2005: Stratigraphy and structure of the southeastern part of the Vértes Mountain (Transdanubian Range, Hungary). - Annual Report of the Geological Institute of Hungary, 2004, 189-203.

Budai, T., Császár, G., Csillag, G., Fodor, L., Gál, N., Kercsmár, Zs., Kordos, L., Pálfalvi, S. \& Selmeczi, I. 2008 : Geology of the Vértes Hills. Explanatory book to the Geological Map of the Vértes Hills (1:50 000). — Geological Institute of Hungary, Budapest, 368 p.

Budai, T., Fodor, L., Kercsmár, Zs., Lantos, Z., Csillag, G. \& SelmecZi, I. 2018: Geological map of the Gerecse Mountains 1:50 000. — Mining the Geological Survey of Hungary, Budapest. ISBN 978-963-671-315-7

CAREY, E. \& BRUNIER, B. 1974: Analyse théorique et numérique d'un modèle mécanique élémantaire appliqué à l'étude d'une population de failles. - Comptes Rendus de l'Académie des Sciences Paris, série D, 279, 891-894.

Cifelli, F., Mattei, M., Chadima, M., HiRT, A.M., Hansen, A. 2005: The origin of the tectonic lineation in extensional basins: combined neutron texture and magnetic analysis on 'undeformed' clays. — Earth and Planetary Science Letters 235, 62-78. https://doi.org/10.1016/ j.epsl.2005.02.042

Ciulavu, D., Dinu, C. \& Cloetingh, S. A. P. L. 2002: Late Cenozoic tectonic evolution of the Transylvanian basin and northeastern part of the Pannonian basin (Romania): Constraints from seismic profiling and numerical modelling. — EGU Stephan Mueller Special Publication Series 3, 105-120. https://doi.org/10.5194/smsps-3-105-2002

CsicseK, L. Á. 2015: A Veszprémi-fennsík Kádárta és Öskü közötti területének szerkezeti elemzése, különös tekintettel a kréta korú rátolódások vizsgálatára. — MSc thesis, Eötvös University, Dept. Physical and Applied Geology \& MTA-ELTE Geological, Geophysical and Space Science Research Group, 114 p.

CSICSEK L. Á. \& FODOR L. 2016: Imbrication of Middle Triassic rocks near Öskü [Bakony Hills, Western Hungary). — Földtani Közlöny 146/4, 355-370.

Csontos, L. 1988: Étude géologique d'une portion des Carpathes Internes, le massif du Bükk (Nord-est de la Hongrie), (stratigraphie, structures, métamorphisme et géodinamique). — PhD. thesis, University Lille Flandres-Artois, $\mathrm{N}^{\circ} 250,327 \mathrm{p}$. 
Csontos, L. 1995: Tertiary tectonic evolution of the Intra-Carpathian area: a review. — Acta Vulcanologica 7, 1-13.

Csontos, L. 1999: Structural outline of the Bükk Mts. (N Hungary). — Földtani Közlöny 129/4, 611-653. (in Hungarian with English abstract)

Csontos, L. \& Bergerat, F. 1993: Reevaluation of the Neogene brittle tectonics of the Mecsek-Villány area (SW Hungary). — Annales Universitatis Scientiarum Budapestinensis de Rolando Eötvös Nominatae, Sectio Geologica 29, 3-12.

Csontos, L. \& HiPs, K. 1997: Structural evolution of the NE part of Hungary. — Przeglqad Geologiczny 45, 1069-1070.

Csontos, L. \& Nagymarosy, A. 1998: The Mid-Hungarian line: a zone of repeated tectonic inversion. - Tectonophysics 297, 51-72. https://doi.org/10.1016/s0040-1951(98)00163-2

Csontos, L., TARI, G., Bergerat, F. \& Fodor, L. 1991: Evolution of the stress fields in the Carpatho-Pannonian area during the Neogene. — Tectonophysics 199, 73-91. https://doi.org/10.1016/0040-1951(91)90119-d

Csontos, L., Nagymarosy A., Horváth, F. \& Kováč, M. 1992: Tertiary evolution of the Intra-Carpathian area: a model. — Tectonophysics 208, 221-241. https://doi.org/10.1016/0040-1951(92)90346-8

Csontos, L., Benkovics, L., Bergerat, F., Mansy, J-L. \& Wórum, G. 2002a: Tertiary deformation history from seismic sections study and fault analysis in a former European Tethyan margin (the Mecsek-Villány area, SW Hungary). — Tectonophysics 357, 81-102. https://doi.org/10.1016/s0040-1951(02)00363-3

Csontos, L., Márton, E., Wórum, G. \& Benkovics, L. 2002b: Geodynamics of SW-Pannonian inselbergs (Mecsek-Villány Mts, SW Hungary): Inferences from a complex structural analysis. - In: Cloetingh, S. A. P. L., Horváth, F., BadA, G. \& LAnkreier, A. C. (eds): Neotectonics and surface processes: the Pannonian basin and Alpine/Carpathian system. — EGU Stephan Mueller Special Publication Series 3, 227-246. https://doi.org/10.5194/smsps-3-227-2002

Csontos, L., Magyari, Á., VanVliet-Lanoë, B. \& Musitz, B. 2005: Neotectonics of the Somogy hills (part II): evidence from seismic sections. — Tectonophysics 410, 63-80. https://doi.org/10.1016/j.tecto.2005.05.049

DABI, G., BAJnóczi, B., SchuBERT, F. \& M. Tóth, T. 2013: The origin and role of a calcite-filled microcrack generation in a metamorphic crystalline complex: The characterization of a fossilised seismic permeability system. — Tectonophysics 608, 792-803. https://doi.org/10.1016/j.tecto.2013.07.039

DEÁK-KövÉr, Sz. 2012: Structure, metamorphism, geochronology and deformation history of Mesozoic formations in the central Rudabánya Hills. — PhD thesis, Eötvös University, Budapest, 152 p.

Detzky-Lórincz, K., Horváth, F. \& Detzky, G. 2002: Neotectonics and its relation to the Mid-Hungarian Mobile Belt. — In: Cloetingh, S. A. P. L., Horváth, F., BADA, G. \& LANKreIER, A. C. (eds): Neotectonics and surface processes: the Pannonian basin and Alpine/Carpathian system. — EGU Stephan Mueller Special Publication Series 3, 247-266. https://doi.org/10.5194/smsps-3-247-2002

DELVAUX, D. \& SPERNER, B. 2003: New aspects of tectonic stress inversion with reference to the TENSOR program. - In: NIEUWLAND, D. A. (ed.): New Insights into Structural Interpretation and Modelling. — Geological Society, London, Special Publications 212, 75_ 100. 0305-8719/03/\$15 https://doi.org/10.1144/gsl.sp.2003.212.01.06

DudKo, A. 1991: Structural elements of the Balaton Highland. — Manuscript, Excursion Guide, Geological Institute of Hungary, 60 p. (in Hungarian)

Dudko, A., Bencze, G. \& SElmeci, I. 1992: The tectonic origin of Miocene basins on the south-western edge of the Transdanubian Central Range. - Annual Report of the Geological Institute of Hungary, 1990, 107-124.

Dudko, A. (ed.), Pistotnik, J., Elečko, M., Vass, D., Hók, J., Vozár, J., Nagy, A. \& ŠEfara, J. 2000: Tectonic Map. — In: Császár, G. (ed.): Danube Region Environmental Geology Programme, DANREG, Explanatory Notes. — Jahrbuch der Geologischen Bundesanstalt 124/4, 493-504.

FiALOWSKI, M. 2018: Deformation and kinematics of the Mónosbél nappe, Bátor area, SW Bükk. — MSc Thesis, MTA-ELTE Geological, Geophysical and Space Science Research Group, \& Eötvös University Dept. Physical and Applied Geology, 82 p.

FODOR, L. 1991: Evolution tectonique et paléo-champs de contrainte oligocène à quaternaire dans la zone de transition des Alpes Orientales-Carpathes Occidentales: Formation et développement des bassins de Vienne et Nord-Pannoniens. — Thèse de Doctorat (PhD. thesis), Université P. et M. Curie, Paris, 215 p.

FODOR, L. 1995: From transpression to transtension: Oligocene-Miocene structural evolution of the Vienna basin and the Eastern AlpineWestern Carpathian junction. — Tectonophysics 242, 151-182. https://doi.org/10.1016/0040-1951(94)00158-6

FodOR, L. 2007: Segment linkage and stress field in transtensional strike-slip fault array: Field examples from the Pannonian Basin. — In: Cunningham, D. \& Mann, P. (eds): Tectonics of Strike-slip Restraining and Releasing Bends. Geological Society, London, Special Publications 290, 417-431. https://doi.org/10.1144/sp290.16

Fodor, L. 2008: Structural geology. In: BudAI, T. \& Fodor, L. (eds): Geology of the Vértes Hills. Explanatory book to the Geological Map of the Vértes Hills 1:50 000. — Geological Institute of Hungary, 145-202, 282-300.

FoDOR, L. 2010: Mesozoic-Cenozoic stress fields and fault patterns in the northwestern part of the Pannonian Basin — methodology and structural analysis. — Doctoral work of the Hungarian Academy of Sciences, 129 p., 7 appendices. (in Hungarian)

FoDOR, L. \& Bíró, I. 2004: Eocene abrasional rocky shore along the Cretaceous Vértessomló thrust (Szarvas-kút, Vértes Hills, Hungary). - Annual Report of the Geological Institute of Hungary, 2002, 153-162. (in Hungarian with English abstract)

Fodor, L. \& Csontos, L. 1998: Structural geological research in Hungary: a review. — Földtani Közlöny 128, 123-143. (in Hungarian with English abstract)

Fodor, L. \& Koroknai, B. 2003: Multiphase folding on the Nagy-kő, Hidvégardó (Torna Unit, NE Hungary). — Annual Report Geological Institute of Hungary, 2000-2001, 133-141. (in Hungarian with English summary)

Fodor, L. \& MAgYARI, Á. 2002: Late Eocene - Miocene structural evolution and sedimentation on the Sas Hill, Budapest, Hungary. — Földtani Közlöny 132, 247-264. (in Hungarian with English abstract)

Fodor, L. \& Marko, F. 1990: Miocene Strike-slip Faulting and Block Rotation in Brezovské Pohorie Mts. (Northwest Carpathians). — Abstracts of the $9^{\text {th }}$ Meeting of R.C.M.N.S., Barcelona, p. 149. 
Fodor, L., Marko, F. \& NemčoK, M. 1990: Evolution microtectonique et paléo-champs de contraintes du Bassin de Vienne. — Geodinamica Acta 4, 147-158. https://doi.org/10.1080/09853111.1990.11105207

Fodor, L., MAgYari, A., KázMÉR, M. \& Fogarasi, A. 1992: Gravity-flow dominated sedimentation on the Buda paleoslope (Hungary). Record of Late Eocene continental escape of the Bakony Unit. — Geologische Rundschau 81, 695-716. https://doi.org/10.1007/ bf01791386

FodOR L., MAGYARI Á., Fogarasi A. \& PALOtÁs K. 1994: Tercier szerkezetfejlődés és késő paleogén üledékképződés Budai-hegységben. A Budai-vonal új értelmezése. — Földtani Közlöny 124, 129-305. (in Hungarian with extended English abstract)

Fodor, L., Csontos, L., BAdA, G., GyÖrfi, I. \& Benkovics, L. 1999: Tertiary tectonic evolution of the Pannonian basin system and neighbouring orogens: a new synthesis of paleostress data. - In: Durand, B., Jolivet, L., Horváth, F. \& SÉranne, M. (eds): The Mediterranean Basins: Tertiary extension within the Alpine Orogen. Geological Society, London, Special Publications 156, 295334. https://doi.org/10.1144/gsl.sp.1999.156.01.15

Fodor, L., Jelen, B., Márton, E., Rifelj, H., Kraljić, M., Kevrić, R., Márton, P., Koroknai, B. \& Báldi-Beke, M. 2002: Miocene to Quaternary deformation, stratigraphy and paleogeography in Northeastern Slovenia and Southwestern Hungary. - Geologija 45, 103-114. https://doi.org/10.5474/geologija.2002.009

Fodor, L., Radócz, Gy., Sztanó, O., Koroknai, B., Csontos, L. \& Harangi, Sz. 2005: Post-Conference Excursion: Tectonics, sedimentation and magmatism along the Darnó Zone. - Geolines 19, 142-162.

Fodor L., HiPs, K., KovÁCs, S., PÉró, Cs., Piros, O., SimON, H. \& Velledits, F. 2006: Evolution of the Aggtelek platform in the AnisianLadinian. Fieldtrip in Aggtelek 19/10/2006-22/10/2006. — Manuscript, Geol. Inst. Hung. \& Hung. Academy of Sciences, 47 p.

Fodor, L., Csillag, G., Lantos, Z., Budai, T., Kercsmár, Zs. \& Selmeczi, I. 2008a: Geological Map of the Vértes Hills, 1:50 000. — Geological Institute of Hungary, Budapest.

Fodor, L. I., Gerdes, A., Dunkl, I., Koroknai, B., Pécskay, Z., Trajanova, M., Horváth, P., Vrabec, M., Jelen, B., Balogh, K. \& Frisch, W. 2008b: Miocene emplacement and rapid cooling of the Pohorje pluton at the Alpine-Pannonian-Dinaric junction: a geochronological and structural study. — Swiss Journal of Earth Sciences 101, Supplement 1, 255-271. https://doi.org/10.1007/s00015-008-1286-9

FODOR L., KERCSMÁr Zs., KöVÉr Sz. 2018: Structure and deformation phases of the Gerecse. — In: BuDAI T. (ed): Geology of the Gerecse Mountains. Mining and Geological Survey of Hungary, 169-208, 370-386. ISBN 978-963-671-312-6.

Forián-SzABó M. 2001: A Bükk hegységi Kis-fennsík földtani Vizsgálata. - MSc thesis, Eötvös University, Dept., General and Historical Geology, $68 \mathrm{p}$.

ForiÁN-SzABó, M. \& Csontos, L. 2002: Tectonic structure of the Kis-fennsík area (Bükk Mts., NE Hungary). — Geologica Carpathica 53/4, 223-234.

Fossen, H., SchultZ, R., Shipton, Z. \& MaIR, K. 2007: Deformation bands in sandstone - a review. — J. Geological Society London 164, 755-769. https://doi.org/10.1144/0016-76492006-036

FÜLÖP J. (szerk.) 1990: Magyarország szerkezetföldtani térképe 1:500 000. — Geological Institute of Hungary.

GÁl, B., Poros, Zs. \& Molnár, F. 2008: A Hárshegyi Homokkő Formáció hidrotermális kifejlődései és azok kapcsolatai regionális földtani eseményekhez. — Földtani Közlöny 138/1, 49-60.

Garaguly, I., Varga, A., Raucsik, B., Schubert, F., Czuppon, Gy. \& Frei, R. 2018: Pervasive early diagenetic dolomitization, subsequent hydrothermal alteration, and late stage hydrocarbon accumulation in a Middle Triassic carbonate sequence (Szeged Basin, SE Hungary). — Marine and Petroleum Geology 98, 270-290. https://doi.org/10.1016/j.marpetgeo.2018.07.024

GERNER P. 1990: Szerkezetföldtani ábrázolások és szerkesztések számítógépen. —Általános Földtani Szemle 25, 192-213.

GRILL, J. 1989: Structural evolution of the Aggtelek-Rudabánya Mts. NE Hungary. — Annual Report of the Hungarian Geology Institute, 1987, 411-432. (in Hungarian with English abstract)

GyAlOG, L. 1992: Data from structural geology of Várgesztes. — Annual Report of the Geological Institute of Hungary, 1990, 69-74. (in Hungarian)

GYÖRFI, I. 1993: Structural evolution of the Neogene basins of SE Hungary and the Apuseni Mts. — MSc thesis, Eötvös University, Dept. General and Historical Geology.

GYÖRFI, I. \& Csontos, L. 1994. Structural evolution of SE Hungary and Neogene basins of the Apuseni Mountains (Romania). Romanian Journal of Tectonics and Regional Geology 75, Supplement 1, 19-20.

Györfi, I., Csontos, L. \& NAGYMAROSY, A. 1999: Early Tertiary structural evolution of the border zone between the Pannonian and Transylvanian basins. - In: Durand, B., Jolivet, L., Horváth, F. \& Séranne, M. (eds): The Mediterranean Basins: Tertiary extension within the Alpine Orogen. — Geological Society, London, Special Publications 156, 251-267. https://doi.org/10.1144/ gsl.sp.1999.156.01.13

Győri, O., Orbán, R., Mindszenty, A., Fodor L., Poros, Zs., Erőss, A., Benkó, Zs. \& Molnár, F. 2014: Origin of the enigmatic red calcite of the Transdanubian Range, Hungary — The representative of a paleo-karstwater system below a bauxitic unconformity. Geofluids 14/4, 459-480. https://doi.org/10.1111/gfl.12088

HaAs J., Budai T., Csontos L., Fodor L. \& KonráD Gy. 2010: Pre-Cenozoic geological map of Hungary, 1:500 000. — Geological Institute of Hungary.

HAVRIL, T., Molson, J.W. \& SzŐNYI, J. 2016: Evolution of fluid flow and heat distribution over geological time scales at the margin of unconfined and confined carbonate sequences - A numerical investigation based on the Buda Thermal Karst analogue. — Marine and Petrolum Geology 78, 738-749. https://doi.org/10.1016/j.marpetgeo.2016.10.001

HÉJA G. 2015: A Keszthelyi-hegység és nyugati előterének szerkezetfejlődése, különös tekintettel a kréta deformációkra. — MSc thesis, Eötvös University, Dept. Physical and Applied Geology and MTA-ELTE Geological, Geophysical and Space Science Research Group, 118 p.

HÉJA, G. 2019: Mesozoic deformations of the western part of the Transdanubian Range. — PhD. thesis, Eötvös University, Dept. Physical and Applied Geology. 
HÉJA, G., KövÉr, Sz., NÉmeth, A., Csillag, G. \& Fodor, L. 2018: Evidences for pre-orogenic passive-margin extension in a Cretaceous fold-and-thrust belt on the basis of combined seismic and field data, (western Transdanubian Range, Hungary). - International Journal of Earth Sciences 107/8, 2955-2973. https://doi.org/10.1007/s00531-018-1637-3, Online ISSN: 1437-3262

HIPS, K. 2001: The structural setting of the Lower Triassic formations in the Aggtelek-Rudabánya Mountains (Northeastern Hungary) as revealed by geologic mapping. — Geologica Carpathica 52/5, 287-299.

HorÁNYI, A., TAKÁCS, Á. \& FodOR, L. 2010: Sedimentological and structural geologic observations at the eastern slope of the Gorba High (,Gyökér ravine”, Western Gerecse Mts., Hungary). — Földtani Közlöny 140/3, 223-234. (in Hungarian with English abstract)

Horváth, B., Fodor, L. \& Kövér, Sz. 2012: Complex thrust sytem and structural evolution in the Henc Valley, Szőlősardó, Rudabánya Hills. - Földtani Közlöny 142/4, 321-338. (in Hungarian with English abstract)

HoRvÁth, F. 1990: Structural evolution of the Pannonian basin: A progress report. — Acta Geodaetica et Geophysica Hungarica 25/3-4, $243-255$.

Horváth, F. 1995: Phases of compression during the evolution of the Pannonian Basin and its bearing on hydrocarbon exploration. Marine and Petroleum Geology 12/8, 837-844. https://doi.org/10.1016/0264-8172(95)98851-u

Horváth, F. \& Rumpler, J. 1984: The Pannonian basement: extension and subsidence of an alpine orogene. — Acta Geologica Hungarica 27, 229-235.

HoRvÁth, F. \& TARI, G. 1999: IBS Pannonian Basin project: a review of the main results and their bearings on hydrocarbon exploration. — In: Durand, B., Jolivet, L., Horváth, F. \& SÉranne, M. (eds): The Mediterranean basins: Tertiary extension within the Alpine orogen. — Geol. Soc. London Spec. Publ. 156, 195-213. https://doi.org/10.1144/gsl.sp.1999.156.01.11

Horváth, F. Musitz, B., Balázs, A.,VÉgh, A. Uhrin, A. Nádor, A. Koroknai, B., Pap, N., Tóth, T. \& Wórum, G. 2015: Evolution of the Pannonian basin and its geothermal resources. — Geothermics 53, 328-352. https://doi.org/10.1016/j.geothermics.2014.07.009

JASKÓ, S. 1988: The Neogene block structure of the Central Hungarian Range. — Földtani Közlöny 118, 325-332.

JASKÓ, S. 1989: A Darnó vonal környékének felső-miocén tektonikája. — Annual Report of the Geological Institute of Hungary, 1987, 395-409.

JIŘÍČEK, R. 1979: Tectonic development of the Carpathian arc in the Oligocene and Neogene. — In: MAHEL, M. (ed): Tectonic profiles through the West Carpathians. Geologícky Ústav Dionyza Stúra, Bratislava, 205-214.

KERCSMÁR, Zs. 1995: Paleoenvironmental reconstruction and tectonosedimentological investigation of the eastern margin of the Tatabánya basin. — MSc thesis, Eötvös University, Dept. Paleontology, 120 p. (in Hungarian)

KerCsmár Zs. 2004: A tatabányai vöröskalcittelérek szerkezetföldtani jelentősége. — Annual Report of the Geological Institute of Hungary, 2002, 163-174. (in Hungarian)

Kercsmár Zs. A Tatabányai-medence földtani felépítésének és fejlődéstörténetének újabb kutatási eredményei tektono-szedimentológiai és üledékföldtani vizsgálatok alapján. — PhD thesis, Eötvös University, Dept. Paleontology, 175 p. (in Hungarian)

KERCSMÁR, Zs. \& FODOR, L. 2005: Syn-sedimentary deformations in the Eocene Tatabánya basin, central Hungary. — Geolines 19, 60-61.

Kernstockova, M. \& Melichar, R. 2009: Numerical paleostress analysis - the limits of automation. — Trabajos de Geología 29, 399403.

KISS A. 1999: A Porvai-medence szerkezetalakulása. — MSc thesis, Eötvös University, Dept. Applied and Environmental Geology, 90 p. (in Hungarian)

KISs A. 2009: Az Északi-Bakony szerkezetalakulása. — PhD thesis, Eötvös University, Dept. Applied and Environmental Geology, 120 p. (in Hungarian)

KISS, A. \& Fodor, L. I. 2007: The Csesznek Zone in the northern Bakony Mts: a newly recognised transpressional element in dextral faults of the Transdanubian Range, western Hungary. — Geologica Carpathica 58/5, 465-475.

Kiss, A., Gellért, B. \& Fodor, L. 2001: Structural history of the Porva Basin in the Northern Bakony Mts. (Western Hungary): Implications for the Mesozoic and Tertiary tectonic evolution of the Transdanubian Range and Pannonian Basin. — Geologica Carpathica 52, 183-190.

KonRÁD, Gy. \& SEBE, K. 2010: New details of young tectonic phenomena in the Western Mecsek Mts and their surroundings. — Földtani Közlöny 140/2, 135-162. (in Hungarian with English abstract)

KoroKNAI B. 2004: Tektonometamorf fejlődés az Upponyi- és Szendrői-paleozoikumban. — PhD thesis, ELTE Földtudományi Doktori Iskola, Földtan-Geofizika Doktori Program, 239 p.

Korpás, L., Fodor, L., Magyari, Á., DÉnES, Gy. \& Oravecz, J. 2002: Geology, karst system and Structural evolution of the Gellért Hill, Budapest, Hungary. — Karszt és Barlang 1998-1999/I-II, 57-93. (in Hungarian with English abstract)

Kovács, Á., Sebe, K., Magyar, I., Szurominé Korecz, A. \& Kovács, E. 2018: Upper Miocene sedimentation and tectonics in the Northern Imbricate Zone (Eastern Mecsek Mts, SW Hungary). — Földtani Közlöny 148/4, 327-340. (in Hungarian with English abstract) https://doi.org/10.23928/foldt.kozl.2018.148.4.327

KóTA E. 2001: A Vértes-hegység DNy-i előterének szerkezetföldtani újraértékelése, a térinformatika alkalmazásával. — MSc thesis, Eötvös University, Dept. Applied and Environmental Geology, 70 p.

Kun-JÁger E., VArga B. \& BAJnóczi B. 1996: A Héreg-Tarjáni-medence szerkezete. — Student work (TDK), Eötvös University, Dept. Applied and Environmental Geology, $52 \mathrm{p}$.

LANTOS, Z. 1995: Gerecsei alsójúra szedimentológiai vizsgálata. — MSc thesis, Eötvös University, Dept. Applied and Environmental Geology, 136 p. (in Hungarian)

LANTOS, Z. 1997: Sediments of a Liassic carbonate slope controlled by strike-slip fault activity (Gerecse Hills, Hungary). — Földtani Közlöny 127/3-4, 291-320.

LANTOS Z. 2004: Liász neptuni telérek és átülepített medenceüledékek nyomában. Karbonát-szedimentológiai esettanulmányok. — PhD thesis, Eötvös University, Dept. Applied and Environmental Geology, 159 p. (in Hungarian with English abstract) 
Lukács, R., Harangi, Sz., Bachmann, O., Guillong, M., Danišík, M., Buret, Y., von Quadt, A., Dunkl, I., Fodor, L., Sliwinski, J., Soós, I. \& SZEPESI, J. 2015: Zircon geochronology and geochemistry to constrain the youngest eruption events and magma evolution of the Mid-Miocene ignimbrite flare-up in the Pannonian basin, eastern-central Europe. - Contribution to Mineralogy and Petrology 170, 52, 26 p. https://doi.org/10.1007/s00410-015-1206-8

Lukács, R., Harangi, Sz., Guillong, M., Bachmann, O., Fodor, L., Buret, Y., Dunkl, I., Sliwinski, J., von Quadt, A., Peytcheva, I. \& Zimmerer, M. 2018: Early to Mid-Miocene syn-extensional massive silicic volcanism in the Pannonian Basin (East-Central Europe): eruption chronology, correlation potential and geodynamic implications. - Earth Science Reviews 179, 1-19. https://doi.org/10.1016/j.earscirev.2018.02.005

MAERTEN, L. 2000: Variation in slip on intersecting normal faults: implications for paleostress inversion. - Journal of Geophysical Research 105, 25553-25565. https://doi.org/10.1029/2000jb900264

MAGYARI, Á. 1991: Relations between Late Eocene tectonics and sedimentation in the Budaörs Hills. — MSc thesis, Eötvös University, Dept. General and Historical Geology, 66 p. (in Hungarian)

MAGYARI Á. 1994: Késő-eocén transzpresszió a Budaörsi hegyekben. — Földtani Közlöny 124, 155-173. (in Hungarian with English abstract)

MagYaRI, Á. 1996: Eocene syn-sedimentary tectonic features and their effect on sedimentation in the Buda Hills, Hungary. — PhD thesis, Eötvös University, Dept. General and Historical Geology, 289 p. (in Hungarian)

MAGYARI, Á. 1998: Törökugrató Hill: Late Eocene positive flower structure on the southwestern part of the Buda Mountains, Budapest. — Földtani Közlöny 124/4, 555-572. (in Hungarian with English abstract)

Marko, F., Kováč, M., Fodor, L. \& SuTOVSKÁ, K. 1990: Deformations and kinematics of a Miocene shear zone in the northern part of the Little Carpathians (Buková Furrow, Hrabník Formation). — Mineralia Slovaca 22, 399-410.

Marko, F., Fodor, L. \& Kováč, M. 1991: Miocene strike-slip faulting and block rotation in the Brezovské pohorie Mts., Western Carpathians. - Mineralia Slovaca 23, 189-200.

Marko, F., PlašIEnKa, D. \& Fodor, L. 1995: Meso-Cenozoic tectonic stress fields within the Alpine-Carpathian transition zone: a review. - Geologica Carpathica 46, 19-27.

Maros Gy. 1986: A Vitányvár környékének tektonikai felvétele. — MSc thesis, Eötvös University, Dept. of Geology, 108 p.

Maros, Gy. 1988: Tectonic survey in the Vitány-vár area, W Hungary. — Annual Report of the Geological Institute of Hungary from 1986, 295-310. (in Hungarian with English abstract)

Maros, Gy., Koroknai, B., Palotás, K., Fodor, L., Dudko, A., Forián-Szabó, M., Zilahi-Sebess, L. \& Bán-Gyôry, E. 2004: Tectonic analysis and structural evolutio of the north-easten Mórágy block. - Annual Report of the Geological Institute of Hungary, 2003, 387-394 (371-386).

Marret, R. \& Allmendinger, R.W. 1990: Kinematic analysis of fault-slip data. — Journal of Structural Geology 12, $973-986$. https://doi.org/10.1016/0191-8141(90)90093-e

MARRETT, R. \& PEACOCK, D.C.P. 1999: Strain and stress. — Journal of Structural Geology 21, 1057-1063. https://doi.org/10.1016/s01918141(99)00020-6

MÁRTON, E. \& FodoR, L. 1995: Combination of paleomagnetic and stress data: a case study from North Hungary. - Tectonophysics 242, 99-114. https://doi.org/10.1016/0040-1951(94)00153-z

MÁRTON, E. \& FODOR, L. 2003: Tertiary paleomagnetic results and structural analysis from the Transdanubian Range (Hungary); sign for rotational disintegration of the Alcapa unit. — Tectonophysics 363, 201-224. https://doi.org/10.1016/s0040-1951(02)00672-8

MÁRTon, E. \& PÉCSKAY, Z. 1995: The Tokay-Vihorlát-Oas-Ignis Triangle: Complex Evaluation of Paleomagnetic and Isotope Age Data from Neogene Volcanics. - Proceedings XVth C.B.G.A. Congress, Geol. Soc. Greece Special Publications 30.

Márton, E., Fodor, L., Jelen, B., Márton, P., RifelJ, H. \& Kevrić, R. 2002: Miocene to Quaternary deformation in NE Slovenia: complex paleomagnetic and structural study. — Journal of Geodynamics 34, 627-651. https://doi.org/10.1016/s0264-3707(02)00036-4

Márton, E., Fodor, L. \& Magyar, I. 2006: Post-Badenian horizontal movements in the Pannonian Basin: complex paleomagneticmicrotectonic study. - Magyar Geofizika 47/4, 178-182. (in Hungarian)

Márton, E., Zelenka, T. \& Márton, P. 2007: Paleomagnetic correlation of Miocene pyroclastics of the Bükk Mts and their forelands. - Central European Geology 50/1, 47-57. https://doi.org/10.1556/CEuGeol.50.2007.1.4

MÉSZÁROS, J. 1982: Major horizontal tectonic dislocation as a guide to mineral prospectors in the western Bakony Mountains. — Annual Report of the Geological Institute of Hungary, 1980, 517-536. (in Hungarian with English abstract)

MÉSZÁRos, J. 1983: Structural and economic geological significance of strike-slip faults in the Bakony Mountains. — Annual Report of the Hungarian Geological Institute 1981, 485-502. (in Hungarian with English abstract)

MolnÁR F. \& Zelenka T. 1995: Fluid inclusion characteristics and paleothermal structure of the adularia-sericite type epithermal deposit at Telkibánya, Tokaj Mts., Northeast Hungary. — Geologica Carpathica 6, 205-215.

MuRÁTI J. 1997: A Gerecse-hegység földtani szerkezetének vizsgálata geofizikai módszerekkel. — MSc thesis, Eötvös University, Dept. Geophysics. (in Hungarian)

NemČoK, M. \& LisLe, R.J. 1995. A stress inversion procedure for polyphase fault/slip data sets. — Journal of Structural Geology 17, 1445-1453. https://doi.org/10.1016/0191-8141(95)00040-k

NemČoK, M., Marko, F., Kováč, M. \& Fodor, L. 1989: Neogene Tectonics and Paleostress changes in the Czechoslovakian Part of the Vienna Basin. — Jahrbuch Geologische Bundesanstalt 132, 443-458.

NÉMETH N. 2005: A Délkeleti-Bükk keleti részének szerkezetföldtani viszonyai. — PhD thesis, Miskolc University.

NÉMETH, N. 2006: Tertiary stress field evolution in the eastern part of the Bükk Mountains, NE Hungary. — Geolines 20, 100-101.

NÉMETH, N. 2007: Structural features of the quarry at the Patkó Cliffs, Bükkzsérc and its surroundings. — Földtani Közlöny 137/4, 473-486.

NÉMETH, N. \& MÁdAI, F. 2003: Early phase ductile deformation elements in limestones of the Eastern part of the Bükk Mountains I. Földtani Közlöny 133/4, 563-583. 
NÉMETH, N. \& MÁDAI, F. 2004: Early phase ductile deformation elements in limestones of the Eastern part of the Bükk Mountains II. — mikroszerkezeti jellemzők. — Földtani Közlöny 134/1, 1-28.

Nuriel, P., Rosenbaum, G., Jian-Xin Zhao, J-X., Feng, Y., Golding, S. D., Villemant, B. \& Weinberger, R. 2012: U-Th dating of striated fault planes. — Geology 40, 647-650. doi: 10.1130/G32970.1 https://doi.org/10.1130/g32970.1

Oláh P., Fodor L., Tóth T., DeÁK A., Drijkoningen, G. \& Horváth F. 2014: A Szentendrei-sziget környéki vízi szeizmikus szelvényezések eredményei. - Földtani Közlöny 144/4, 359-380.

ORAVECz É. 2016: A jura Bükkzsérci Mészkő korai deformációs szerkezeteinek vizsgálata. — Student work (TDK), Eötvös University, MTA-ELTE Geological, Geophysical and Space Science Research Group, 66 p.

OrAVECZ, É. 2019: Complex deformation history of the Silica nappe, Aggtelek Mts: Inherited Triassic salt structures and their role during the Alpine deformation. — MSc Thesis, ELTE Földrajz-Földtudományi Intézet, 148 p. (in Hungarian with English abstract)

OrAVECZ, É., FODOR, L. \& KövÉr, Sz. 2017: Significance of Jurassic early deformation structures in the SW-Bükk Mts. — In: ŠARIĆ, K., Prelević, D., Sudar, M. \& Cvetković, V. (eds): Émile Argand Conference - 13 ${ }^{\text {th }}$ Workshop on Alpine Geological Studies — September $7^{\text {th }}-18^{\text {th }} 2017$, Zlatibor Mts., Serbia, EGU series, Abstract Volume, p. 77.

Oravecz, É., FodOR, L. \& KövÉr, Sz. 2018: Structural mapping, well data and stress field analysis in the surroundings of the Nekézseny Thrust Fault, NE Hungary — Geology, Geophysics \& Environment 44/1, 181-182.

ORLICKY, O. 1995: Paleomagnetism of neovolcanics of the East- Slovak Lowlands and Zemplínske vrchy Mts.: A study of the tectonics applying the paleomagnetic data (Western Carpathians). — Geologica Carpathica 47, 13-20.

Palotai, M. 2013: Oligocene-Miocene Tectonic Evolution of the Central Part of the Mid-Hungarian Shear Zone. - PhD thesis, Eötvös Loránd University, Dept. General and Historical Geology, 147 p.

PAlotai, M. \& Csontos, L. 2010: Strike-slip reactivation of a Paleogene to Miocene fold and thrust belt along the central part of the MidHungarian Shear Zone. — Geologica Carpathica 61/6, 483-493. https://doi.org/10.2478/v10096-010-0030-3

Palotai, M., Csontos, L., DövÉnyi, P. \& Galácz, A. 2006a: Redeposited blocks in Upper Jurassic sediments on Eperkés Hill. — Földtani Közlöny 136/3, 325-346. (in Hungarian with English abstract)

Palotai M., Csontos L. \& DövÉNYi P. 2006b: A kesztölci mezozoos (felső-jura) előfordulás terepi és geoelektromos vizsgálata. — Földtani Közlöny 136/3, 347-368. (in Hungarian with English abstract)

Palotai M., Mindszenty A., Kopecskó K. \& Poros Zs. 2012: Az Ínség-kő geológiája. — Földtani Közlöny 142/3, $243-250$.

PAlotás K. 1991: A Tétényi-fennsík szedimentológiája és tektonikája a szarmatában. — MSc thesis, Eötvös University, Dept., General and Historical Geology, 103 p.

Palotás, K. 1994: Synsedimentary Sarmatian fractures in the Tétény plateau. — Földtani Közlöny 124, 207-210. (in Hungarian)

PETRIK, A. B. 2009: Interpretation of the results of microtectonic measurements performed with respect to mesozoic formations of the Villány Hills, Hungary. — Földtani Közlöny 139/3, 217-236.

Petrik, A. B. 2016: Structural evolution of the southern Bükk foreland. — PhD thesis, Eötvös University, Dept. of Physcial and Applied Geology, 208 p. (in Hungarian with English abstract)

PETriK, A., BEKE, B. \& FoDOR, L. 2014: Combined analysis of faults and deformation bands reveals the Cenozoic structural evolution of the southern Bükk foreland (Hungary). — Tectonophysics 633, 43-62. https://doi.org/10.1016/j.tecto.2014.06.029,

Petrik, A., BeKe, B., Fodor, L. \& LuKÁcs, R. 2016: Cenozoic structural evolution of the southwestern Bükk Mts. and the southern part of the Darnó Deformation Belt (NE Hungary). — Geologica Carpathica 67/1, 83-104. ISSN online:1336-8052 / print: 1335-0552 https://doi.org/10.1515/geoca-2016-0005

Petrik, A., Fodor, L., Bereczki, L., Klembala, Zs., LukÁcs, R., Baranyi, V. Beke, B. \& Harangi, Sz. 2019: Variation in style of magmatism and emplacement mechanism induced by changes in basin environments and stress fields (Pannonian Basin, Central Europe). — Basin Research 31/2, 380-404, DOI: 10.1111/bre.12326.

PogÁcsÁs Gy., LAKatos L., BARVitz A., VAKARCs G. \& FARKAs Cs. 1989: Pliocén-quarter oldaleltolódások a Nagyalföldön. — Általános Földtani Szemle 24, 149-169.

PogÁcsÁs, Gy., Mattick, R. E., TARI, G. \& VÁRNAI, P. 1994: Structural Control on Hydrocarbon accumulation in the Pannonian Basin, Hungary. - In: TeleKI, P., MATtick, R. E. \& KóKAI, J. (eds): Basin Analysis in Petroleum Exploration. Springer, Netherland, $221-235$.

RoBERTS, N. M. W. \& WALKER, R. J. 2016: U-Pb geochronology of calcite-mineralized faults: Absolute timing of rift-related fault events on the northeast Atlantic margin. — Geology 44/7, 531-534. doi:10.1130/G37868.1 https://doi.org/10.1130/g37868.1

Royden, L. H. \& Horváth, F. (eds), 1988: The Pannonian basin. A Study in Basin Evolution. — American Association of Petroleum Geologists, Memoir 45.

RUSZKICZAY-RÜDIGER, Zs. 2007. Tectonic and climatic forcing in Quaternary landscape evolution in the Central Pannonian Basin: A quantitative, geomorphological, geochronological and structural analysis. — PhD Thesis, Vrije Universiteit, Amsterdam, 149 p.

RuszkicZAY-RÜDIGER, Zs., Fodor, L. I. \& HoRvÁTH, E. 2007: Neotectonics and Quaternary landscape evolution of the Gödöllő Hills, Central Pannonian Basin, Hungary. — Global and Planetary Change 58/1-4, 181-196. https://doi.org/10.1016/j.gloplacha. 2007.02.010

Sant, K., Palcu, D. V., Mandic, O. \& Krijgsman, W. 2017: Changing seas in the Early-Middle Miocene of Central Europe: a Mediterranean approach to Paratethyan stratigraphy. — Terra Nova 29, 273-281. https://doi.org/10.1111/ter.12273

SASVÁRI Á. 2003: A bakonyi Telegdi Róth-vonal vizsgálata. — MSc thesis, Eötvös University, Dept. General and Historical Geology, 109 p.

SASVÁRI Á. 2008a: A Gerecse feszültségterének fejlődése a Dunántúli-középhegységről készült publikációk tükrében: irodalmi áttekintés. — Földtani Közlöny 138, 147-164.

SASVÁRI Á. 2008b: Rövidüléshez köthető deformációs jelenségek a Gerecse területén. — Földtani Közlöny 138, 385-402.

SASVÁRI Á. 2009a: Egy „különleges kőzetmozgási alakulat” értelmezése — nyíráshoz kapcsolható szerkezetek a gerecsei Ördöggátikőfejtőben. — Földtani Közlöny 139/3-4, 341-352. 
SASVÁRI Á. 2009b: Középsô-kréta rövidüléses deformáció és szerkezeti betemetôdés a Gerecse területén. — PhD thesis, Eötvös University, Dept. Physical and Applied Geology, 164 p.

SAsvÁri, Á., KISS, A. \& Csontos, L. 2007: Paleostress investigation and kinematic analysis along the Telegdi Roth Fault (Bakony Mountains, western Hungary). — Geologica Carpathica 58, 477-486.

SASVÁri, T. \& KondEla, J. 2009: Structural characteristics of epithermal, low-sulphide precious metals mineralization at Telkibánya, Tokaj Mountains, Hungary- In: NÉMETH, N. \& HARTAI, É. (eds): Telkibánya Geology. Publications of the University of Miskolc, Series A, Mining 78, 71-96.

SCHERMAn B. 2018: A mónosbéli- és a Szarvaskői-takarók mezozoos deformációja a Villó-völgy-Almár-völgy szelvényben. — MSc thesis, Eötvös University, Dept. Physical and Applied Geology and MTA-ELTE Geological, Geophysical and Space Science Research Group, $122 \mathrm{p}$.

Scherman, B., Fialowski, M., Fodor, L., Kövér, Sz. \& Reiser, M. 2018: Preliminary observations on low temperature shearing and folding of Middle Jurassic siliciclastic formations, SW Bükk, Hungary. - 17 th Symposium of Tectonics, Structural Geology and Crystalline Geology. Institute of Geological Sciences, Friedrich Schiller University, Jena, p. 109.

Sebe K. \& Dezső J. 2008: A pécsi Havi-hegy hasadékbarlangja. — Karszt és Barlang 2004-2005, 23-25.

Sebe, K. \& KonRáD, Gy. 2009: Post-conference excursion: Paleogeographic relationship of the Mecsek region and the Mecsekalja Dislocation Zone. - Proceedings of the $7^{\text {th }}$ Meeting of the CETeG, Pécs, Hungary, 74-82.

Sipos, A. A. 2013: Statistical tests for rock physical parameters given by near isotropic, stochastic tensors. — Magyar Geofizika 54, 170_ 184. (in Hungarian)

Sipos, A. A., MÁrTON, E. \& Fodor, L. 2018: Reconstruction of early phase deformations by integrated magnetic and mesotectonic data evaluation. - Tectonophysics 726, 73-85. doi.org/10.1016/ j.tecto.2018.01.019

Sipos-Benkő, K., Márton, E., Fodor, L. I. \& Pethe, M. 2014: An integrated magnetic susceptibility anisotropy (AMS) and structural geological study on Cenozoic clay rich sediments from the Transdanubian Range. - Central European Geology 51/1, 21-52, https://doi.org/10.1556/CEuGeol.57.2014.1.2

SKORDAY, E. 2010: Az Ortaháza-kilimáni-gerinc és északi előterének szerkezete. — MSc thesis, Eötvös University, Dept. General and Applied Geology, 88 p.

SPerner, B. \& Zweigel, P. 2010: A plea for more caution in fault-slip analysis. — Tectonophysics 482, 29-41. https://doi.org/10.1016/ j.tecto.2009.07.019.

Szives, O., Fodor, L., Fogarasi, A. \& Kövér, Sz. 2018: Integrated calcareous nannofossil and ammonite data from the upper Barremian-lower Albian of the northeastern Transdanubian Range (central Hungary): stratigraphical implications and consequences for dating tectonic events. — Cretaceous Research 91, 229-250. https://doi.org/10.1016/j.cretres.2018.06.005

SzŐ́CS, E., BEKE, B., HIPS, K. \& FODOR, L. 2018: Structural diagenesis and carbonate cementation of Lower Miocene sandstone: Implications for basinal fluid flow and reservoir quality (Northern Hungary). — Geophysical Research Abstracts 20, EGU20187130.

Szabó, B., Schubert, F., M. Tóth, T. \& Steinbach, G. 2016: Palaeofluid evolution in a fractured basalt hosted reservoir in the ÜllésRuzsa-Bordány area, southern sector of the Pannonian Basin. - Geologia Croatica 69/3, 281-293. https://doi.org/10.4154/ gc. 2016.25

SzTANó, O. \& Fodor, L. 1997: Bathyal slope deposits in the Paleogene Basin: a case study of the Upper Eocene Piszke Marl (Nyergesújfalu, Sánc Hill, Hungary). — Földtani Közlöny 127, 267-290.

TARI G. 1987: A Vatta-maklári árok neogén tektonikája szeizmikus szelvények értelmezése alapján. — MSc thesis, Eötvös University, Department of Geophysics, $129 \mathrm{p}$.

TARI, G. 1988: Strike-slip origin of the Vatta-Maklár trough, northeastern Hungary. — Acta Geologica Hungarica 31, 101-109.

TARI, G. 1991: Multiple Miocene block rotation in the Bakony Mountains, Transdanubian Central Range, Hungary. — Tectonophysics 199, 93-103. https://doi.org/10.1016/0040-1951(91)90120-h

TARI, G. 1993: Neogene transpression in the Northern Thrust Zone, Mecsek Mts. Hungary. - Annales Universitatis Scientiarum Budapestinensis de Rolando Eötvös Nominatae, Sectio Geologica 29, 165-187.

TARI, G. 1994: Alpine Tectonics of the Pannonian basin. — PhD. thesis, Rice University, Texas, USA, $501 \mathrm{p}$.

TARI, G. 1996: Extreme crustal extension in the Rába river extensional corridor (Austria/Hungary). — Mitteilungen der Gesellschaft der Geologie- und Bergbaustudenten in Österreich 41, 1-18.

TARI, G. \& HoRVÁth, F. 2010: Eo-Alpine evolution of the Transdanubian Range in the nappe system of the Eastern Alps: revival of a 15 years tectonic model. — Földtani Közlöny 140/4, 483-510. (in Hungarian with English abstract)

Tari, G., Horváth, F. \& Rumpler, J. 1992: Styles of extension in the Pannonian Basin. — Tectonophysics 208, $203-219$. https://doi.org/10.1016/b978-0-444-89912-5.50016-8

TARI, G., BÁLDI, T. \& BÁLDI-BEKE, M. 1993: Paleogene retroarc flexural basin beneath the Neogene Pannonian Basin: a geodynamical model. — Tectonophysics 226, 433-455. https://doi.org/10.1016/0040-1951(93)90131-3

TARI, G., Horváth, F. \& WeIr, G. 1995: Palinspastic reconstruction of the Alpine/Carpathian/Pannonian system. — In: Horváth, F., TARI, G. \& BOKOR, Cs. (eds): Extensional collapse of the Alpine orogene and Hydrocarbon prospects in the Basement and Basin Fill of the Western Pannonian Basin. AAPG International Conference and Exhibition, Nice, France, Guidebook to fieldtrip No. 6, Hungary, 119-132.

Tari, G., Dövényi, P., Dunkl, I., Horváth, F., Lenkey, L., Stefanescu, M., Szafián, P. \& Tóth, T. 1999: Lithospheric structure of the Pannonian basin derived from seismic, gravity and geothermal data. In: Durand, B., Jolivet, L., Horváth, F. \& SÉranne, M. (eds): The Mediterranean Basins: Tertiary extension within the Alpine Orogen. _ Geological Society Special Publications 156, $215-250$. https://doi.org/10.1144/gsl.sp.1999.156.01.12 
TiBALDI, A. 1992: The role of transcurrent intra-arc tectonics in the configuration of a volcanic arc. - Terra Nova 4, 567-577. https://doi.org/10.1111/j.1365-3121.1992.tb00598.x

Tischler, M., Gröger, H. R., FügenschuH, B. \& SchMid, S. 2007: Miocene tectonics of the Maramures area (Northern Romania): implications for the Mid-Hungarian fault zone. — International Journal of Earth Sciences (Geologische Rundschau) 96, $473-496$. https://doi.org/10.1007/s00531-006-0110-x

TomlJenović, B. \& Csontos, L. 2001: Neogene-Quaternary structures in the border zone between Alps, Dinarides and Pannonian basin (Hrvatsko zagorje and Karlovac basin, Croatia). — International Journal of Earth Sciences 90, 560-578. https://doi.org/10.1007/ s005310000176

Tomljenović, B., Csontos, L., MÁrton, E. \& MÁrton, P. 2008: Tectonic evolution of the northwestern Internal Dinarides as constrained by structures and rotation of Medvednica Mountains, North Croatia. - In: SIEGESMUND, S., FÜGENSCHUH, B. \& FroITZHEIM, N. (eds): Tectonic Aspects of the Alpine-Dinaride-Carpathian System. — Geological Society, London, Special Publications 298, $145-167$. https://doi.org/10.1144/sp298.8

Tomor-Thirring, J. 1936: Die tektonischen Verhältnisse des Gebirgszuges von Csesznek. — Földtani Közlöny 66, $199-213$.

Tótн Á. 2018: A Balaton-felvidék felszínalatti vizeinek hidraulikai kapcsolata a Bakonnyal és a Balatonnal. — PhD thesis, Eötvös University, Dept. Physical and Applied Geology.

Tóтн, M. T. 2018: Fracture network characterization using 1D and 2D data of the Mórágy Granite body, southern Hungary. — Journal of Structural Geology 113, 176-187.

Törő, B., SzTAnó, O. \& Fodor, L. 2012: Inherited and syndepositional structural control on the evolution of Lake Pannon's slope, Northern Somogy, Hungary. — Földtani Közlöny 142/4, 339-356. (in Hungarian with English abstract).

VÁRKONYI, A. 2012: Late Cenozoic deformation and sedimentation based on seismic and borehole data in North Somogy (south-western Hungary). — MSc thesis, Eötvös University, Depts. Regional Geology, Physical and Applied Geology \& MTA-ELTE Geological, Geophysical and Space Science Research Group, 97 p.

TÖrÖK, Á., BARsi, Á., BöGÖly, Gy., LovAs, T., SomOGYI, Á. \& GörÖG, P. 2018: Slope stability and rockfall assessment of volcanic tuffs using RPAS with 2-D FEM slope modelling. — Natural Hazards and Earth System Sciences 18, 583-597. https://doi.org/10.5194/ nhess-18-583-2018

VAss, D., Hók, J., Kováč, P. \& ElEčKo, M. 1993: The Paleogene and Neogene tectonic events of the Southern Slovakia depression in the light of the stress-field analysis. — Mineralia Slovaca 25, 79-92. (in Slovakian with English summary)

Visnovitz, F., Horváth, F., FeKete, N. \& SpIEss, V. 2015: Strike-slip tectonics in the Pannonian basin based on seismic surveys at Lake Balaton. — International Journal of Earth Sciences (Geol. Rundsch.) 104/8, 2273-2285. https://doi.org/10.1007/S00531-015-1179.x.

VRABEC, M. 1999: Style of postsedimentary deformation in the Plio-Quaternary Velenje basin, Slovenia. — Neues Jahrbuch für Geologie und Paläontologie Monatschefte 8, 449-463.

VRABEC, M., ČAR, J. \& VEBER, I. 1999: Kinematics of the Šoštanj fault in the Velenje basin area. — Insights from subsurface data and paleostress analysis. - Rudarsko-metalurški zbornik 46/3, 623-634.

WALlaCE, R. E. 1951: Geometry of shearing stress and relation to faulting. _ Journal of Geology 59, 118-130. https:/doi.org/ $10.1086 / 625831$

Wórum G. 1999: A Mecsek-Villányi térség szerkezete és fejlődéstörténeti eseményei szeizmikus szelvények alapján. — MSc thesis, Eötvös University, Dept. Geophysics.

Yamaj, A., Otsubo, M. \& SATo, K. 2006: Paleostress analysis using the Hough transform for separating stresses from heterogeneous fault-slip data. — Journal of Structural Geology 28/6, 980-990. https://doi.org/10.1016/j.jsg.2006.03.016

ŽAlOHAR, J. \& VRABEC, M. 2008: Combined kinematic and paleostress analysis of fault-slip data: The Multiple-slip method. — Journal of Structural Geology 30, 1603-1613. https://doi.org/10.1016/j.jsg.2008.09.004

ZELENKA, T. 1975: Structural-igneous setting of the deep-seated base ore metal deposit of Recsk. — Földtani Közlöny 105, 58-597. (in Hungarian with English abstract)

ZelenkA, T. \& Horváth, J. 2009: Characteristics of the Telkibánya veins. — In: NÉMETH, N. \& HaRTAI, É. (eds): Telkibánya geology. Publications of the University of Miskolc, Series A, Mining 78, 71-96.

Zelenka T., Kaló J. \& NÉMETH N. 2005: Az alsótelekesi gipsz-anhidrit dóm szerkezete. — Földtani Közlöny 135/4, $493-511$.

Zoback, M. D., Zoback, M. L., Mount, V. S., Suppe, J., EAton, J. P., Healy, J. H., Oppenheimer. D., Reasenberg, P., Jones, L., Raleigh, C. B., Wong, I. G., Scotti, O. \& Wentworth, C. 1987: New evidence on the state of stress of the san andreas fault system. - Science 238, (4830), 1105-1111. https://doi.org/10.1130/0091-7613(1987)15\%3C1143:sosnts\%3E2.0.co;2

Manuscript recieved: 28/06/2019 